Florida International University FIU Digital Commons

4-3-2003

\title{
Playing Miami : Afrocuban performance artists negotiating cubanidad
}

Kameelah Nicole Benjamin-Fuller

Florida International University

DOI: $10.25148 /$ etd.FI14051101

Follow this and additional works at: https://digitalcommons.fiu.edu/etd

Part of the African Studies Commons, and the Latin American Languages and Societies Commons

\section{Recommended Citation}

Benjamin-Fuller, Kameelah Nicole, "Playing Miami : Afrocuban performance artists negotiating cubanidad" (2003). FIU Electronic Theses and Dissertations. 1605.

https://digitalcommons.fiu.edu/etd/1605 
FLORIDA INTERNATIONAL UNIVERSITY

Miami, Florida

PLAYING MIAMI: AFROCUBAN PERFORMANCE ARTISTS

NEGOTIATING CUBANIDAD

A thesis submitted in partial fulfillment of the

requirements for the degree of

MASTER OF ARTS

in

AFRICAN NEW WORLD STUDIES

by

Kameelah Nicole Benjamin-Fuller

2003 
To: Dean Arthur W. Herriott

College of Arts and Sciences

This thesis, written by Kameelah Nicole Benjamin-Fuller, and entitled Playing Miami:

AfroCuban Performance Artists Negotiating Cubanidad, having been approved in respect to style and intellectual content, is referred to you for judgment.

We have read this thesis and recommend that it be approved.

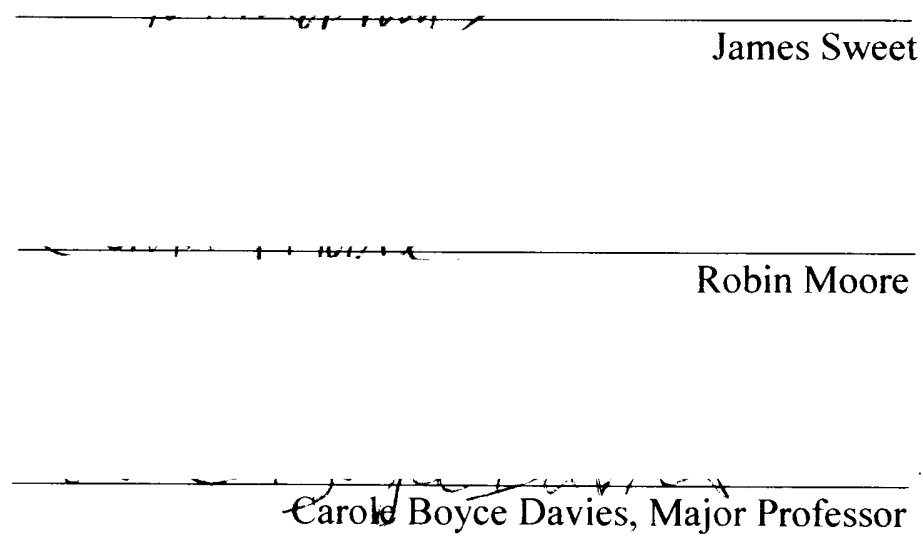

Date of Defense: April 3, 2003

The thesis of Kameelah Nicole Benjamin-Fuller is approved.

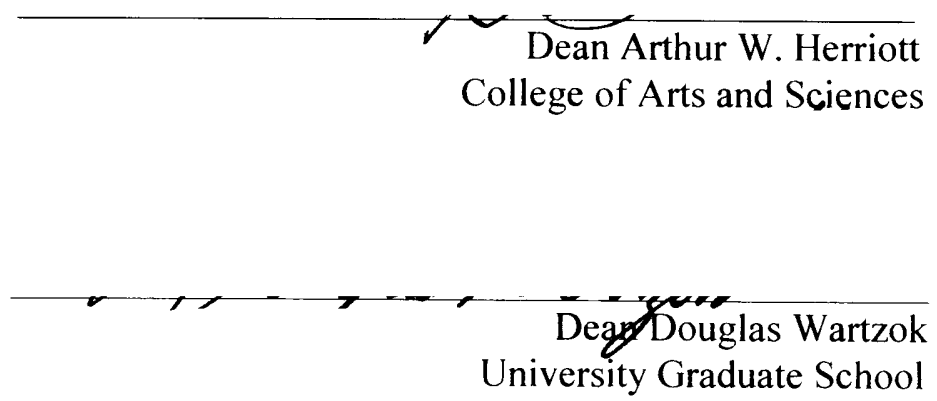

Florida International University, 2003 
(C) Copyright 2003 by Kameelah Nicole Benjamin-Fuller All rights reserved. 


\section{DEDICATION}

To my grandmother Doris Benjamin, my mother Vivian, my brother Jamal, and my sister/cousin Renee. And to my grandfather, Uriah Benjamin, in loving memory (1916 - 1998).I am because you believe. 


\section{ACKNOWLEDGMENTS}

By ancestors, by blessings, by the infinite possibilities of the Universe, and the Creator, I have come to a place of learning, growth, creativity, and humility. For all that is before me, I give thanks those who have illuminated the path....

It is with the great honor that I recognize the distinguished members of my committee for their guidance and expertise. Dr. Carole Boyce Davies, your sense of theoretical purpose and innovative approach to academic work, have shaped not only this project, but my personal and professional growth. Dr. Robin Moore, before meeting you, your work provided inspiration and after your invaluable interventions, your dedication provided meaning. Dr. James Sweet, thank you for your patience and unwavering support. In many ways you helped this project "get off the ground."

My deepest gratitude is offered to Rosa Henriquez, African-New World Studies Program Coordinator. Thank you for your knowledge, encouragement, and friendship. For the countless conversations and suggestions, I offer sincere thanks to kindred spirit, Christopher Roberson. For your invaluable friendship and assistance conceptualizing this project, special thanks to Jafari Sinclaire Allen. Dr. Terry Rey, your guidance and blessings have contributed greatly to this process. Special thanks to Dr. Nadine Fernandez for providing critical references and contextual data in the early stages of this project.

I wish to recognize the support of several FIU and visiting faculty members who have contributed to the completion of this project: Dr. Hugh Gladwin, Dr. Brian Meeks, Dr. Sydney Mintz, Dr. Jean Rahier, and Dr. Ivelaw Griffith. I would also like to recognize faculty of Cornell University who directed me towards FIU and facilitated early interests in 
Afro-Latino studies. Thanks to Dr. Mary Katzenstien, Dr. Vilma Santiago-Irizarry, and Dr. Amy Villarejo.

It is with the utmost respect and admiration that I acknowledge my colleagues, Audrey Gelin, Natasha Marks, and Marissa Thomas. For your friendship and creative sensibilities which made this project imaginable, thanks to Tricia Cassidy, James Stuckey, Cheryl Roberts, Phillip Alexander, William Walker, Susanna Ramos, Alex Krueter, and Danielle Natividad. Sincere thanks to Jaribu Hill for your wonderful advice and dedication to academia/activism work. To my dear friend Susana Milnes, thank you for your boundless faith. To my sister/friend, Thais Council, many thanks for your kindness and constant support. Special thanks to my uncles, lke, and Kenny Benjamin, Grandma and Mr. Boone, my father, Jacob Fuller, Lucille Fuller, Aunt Sally, and the countless family members who have made this professional moment feasible.

Thank you to my mentor Neri Torres...I am forever indebted to you and am humbled to have been part of the amazing, historic, and innovative work that you do. And to the artists and innovators without whom this project would not be possible, I dedicate the success of this thesis to my gifted teachers Arulan Torres, Ernesto Simpson, Adrian Castro, Lazaro, Tommy Cruz, Luis Bofill, Arturo Sandoval, Leila Cobo, Bruno Del Granado, and Gabriel Baptiste. Your dedication has provided unimaginable inspiration. 
I have rejected propaganda teaching me about the beautiful the truly rare:

Supposedly the ocean at the hushpoint of the shore supposedly

the ocean at the hushpoint of the shore is beautiful for instance but the beautiful can stay out there unless I see a bird seize sandflies or your self approach me laughing out a sound to spoil the pretty picture....

- June Jordan, from "Poem on New Year's Eve" (1I) (Comforted by the thought that you are now with/of the ancestors...) 


\section{ABSTRACT OF THE THESIS \\ PLAYING MIAMI: AFROCUBAN PERFORMANCE ARTISTS \\ NEGOTIATING CUBANIDAD \\ by}

Kameelah Nicole Benjamin-Fuller

Florida International University, 2003

Miami, Florida

Professor Carole Boyce Davies, Major Professor

The social scripts that are deeply involved in cultural production by AfroCuban identified artists in Miami, during the late nineties to the present, participate in a climate that is informed by and feeds from the so-called Latin Explosion of this time period. More specifically, varying historical, socioeconomic, and geopolitical trajectories have placed Africa and African-based religion and cultural production (via music and theatre) at the center of Cuban national identity. The purpose of this study is to facilitate a discussion of the experiences of AfroCuban performance artists and the climate for production, given the aforementioned dynamics, in mass media. These experiences are directed by a study of transnational structures for cultural production (including the more recent memory-shadow of hip-hop culture in Cuba) and discourse that engages theories of modernity, authenticity, and resistance. Through the interventions of artists, producers, and distributors via their art and business, the text identifies and resists the pervasive oppression of stereotype, dehumanization (Othering), and essentialism. 


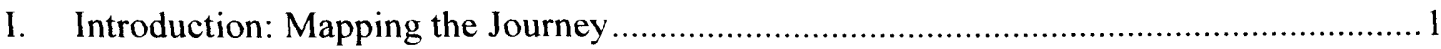

II. Imaging the Other: Memory-Shadows and the Image ………......................................22

III. Commodifying the Other: The Shadowing-Memory in Music and Film ...........................36

IV. Playing the Other: The Industry of Nostalgia - Vignettes of the Venue and the Artist.....60

V. Conclusion - Contextualizing the Journey: Linking Labor, Ideology, and Culture ............83

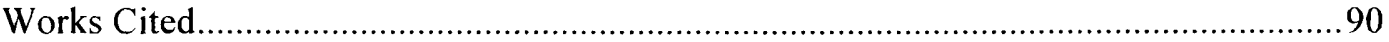


ONE

Introduction: Mapping the Journey

That mainstream culture has periodically expressed desire for subaltern art has never obligated anyone to deal with subaltern peoples as human beings, compatriots, or artists.

(Fusco 29)

Just because Univision uses Celia Cruz in a few commercials and a novela, does not mean that as a television station you are not promoting racism. Every time I turn on to watch Univision, I ask myself: Where are the black Latinos? Do we not exist? Do Latinos only range from light brown to 'huero' (with hueros, especially among females, getting the most representation)? ... Latinos come in so many hues, yet we neglect or make fun of the darkest ones. I implore you to make an effort to change your programming because it is causing millions of your darker-skinned children to hate themselves. It is amazing that during the sixties and currently we are fighting against the negative depiction or lack there of of Latinos on 'mainstream' television networks. I ask you to look within and put your own house in order. -Wendell A. Osborne to Univision

$\sim$ By Way of Introduction: Key Terms and Points of Inquiry

\section{Cubanidad}

Cubanidad, Cubanismo, Latinidad, and Hispanidad are words that can imply a finite essence or as Francis Aparicio suggests, speaking of Latinidad, such constructions are a process which "allow[s] us to explore moments of convergences and divergences in the formation of Latino/a (post)colonial subjectivities..." (Aparicio 93). These concepts reflect the heart and soul of a people that may be linked by culture, country, nationality, region, and language. They are terms that can confine and restrict, and are thus capable of essentialism in 
their construction and use. Yet, they may also hold meaning and substance for those who choose to locate themselves and/or their culture within the often misunderstood and misrepresented context. To mainstream Cuban identity suggests, for the purpose of this discussion, media projects that present Cuban identity to a diverse consumer-base, often with a secure budget, sponsorship, broad distribution, and marketing abilities. To negotiate this identity, specifically through the arts, often means struggling/working in and around commercial, global/local, and independent networks within arts and entertainment industries.

\section{AfroCuban}

Black identity in the course of this study will be channeled through the qualifier AfroCuban. AfroCuban as a principal term is multifold as it informs cultural and ethnic identities. Here, it will describe a genre of music, an ethnoreligious/spiritual history, a choice of self-identification, and social interpellation by/of black Cubans. Several scholars and Cuban-identified peoples are reluctant to engage the term, claiming that "AfroCuban" is redundant. Rather, they suggest that the culture attributed to this construction can be interpreted as simply "Cuban." Still, others resist the assimilation of black Cuban identities and cultural production into the at times hegemonic appropriation of Cuban culture.

Likewise, many white Cubans identify with or as AfroCuban based on their socioculturalreligious affiliations.

"Cuban music is basically Afro-Cuban. Why say Afro?" "We may be white on the outside but we are Yoruba on the inside." "Most of us grew up with blacks. My nanny was black and we loved her. We are all part of each other, we are both white and black because of the people we grew up with and the culture we share." - "Slavery is rough -- exile is even rougher" "I am white, but maybe I should feel 
like a mulata, because the culture... its like, in my blood, in

my veins. African culture that is." -Statements from white Cubans

at an Ife-lle AfroCuban festival event

(October 2000, Books and Books, Inc. Coral Gables, FL)

Evident from the comments above, Afro or black Cuban identity, as a concept, is highly contested. Further explorations of the label/identity/culture reveal ideological statements that locate geographic, religious, artistic, political, and/or economic perspectives. Compounded, Afro-Cuban (here used as AfroCuban), resists a history of ethnoreligious oppression, misrepresentation, and socioeconomic devaluation. At the same time it is located at the juncture of a post-revolutionary moment that both aims to unite a population under Cubanidad, but struggles with the inclusion of Afro-Caribbean/black Cuban peoples and the potential threat of a so-called African presence. I make these distinctions, for as black Cuban artist Coco Fusco states, "respective colonialisms [U.S., Latin America and the Caribbean] engendered different social constructions of race, despite shared legacies of slavery, sexual exploitation... and segregationist legislation" (Fusco 23). Intending not to impose on Cuba and Cuban immigrants/exiles a U.S. oriented ideology on systems of stratification (race, color, class, age, gender, sex, ability), the study focuses on the ways these systems interact, collide and collaborate in oppression/resistance and the products of such relationships.

\section{Afro-Latino: Considerations}

Brazilian intellectual Abdias do Nascimento's work, although concentrated on the complexities of race in Brazil, offers a critical intervention for unpacking the logic of race relations in Cuba. In the occasional paper, "Pan Africanism, Negritude and the African Experience" he argues that miscegenation enables the political and social erasure and/or 
marginalization of the "presence" of African identity and African peoples in the construction of national/ethnic identities in Latin America and the Spanish-speaking Caribbean. The concept of African "presence" in Latin American and Caribbean countries can be highly problematic for do Nascimento, in that (for example) Brazil is "demographically and culturally an African country" (Nascimento 88). Thus, the implication of presence assumes a temporal mytho-reductionist reality for Brazilian identity and the importance of AfroBrazilians to Brazilian society. This limiting framework is central to the organization of not only Brazilian, but also other Latin American identities and partial, penumbral concepts of Latinidad or Hispanidad. Furthermore, the culmination of such racisms emerged from the "cornerstone" of Latin racism, which Nascimento describes as:

...the compulsion to identify with European values, aesthetics, and criteria of personal beauty, creating negative psychological complexes [is distinguishable because]...rather than being seen as one of the white supermacism's many faces or as a legacy left by colonialism, this compulsion to whiteness is presented as a proof of positive Latin antiracism! (Nascimento 92)

This myth of anti-racism that is found throughout many countries in Latin America and the Caribbean also provides a foundation for the rhetoric of Cuba and Cubans in pre and postrevolution Martí/Maceo ideologies. It is an extremely perverse and pervasive myth that has contributed to the invisibility of Afro-Latin peoples and subsequently Afro-Latin Studies.

\section{Memory-Shadows}

The social scripts that are deeply involved in cultural production by AfroCuban identified artists in Miami, during the late nineties to the present, participate in a climate that is informed by and feeds from the so-called Latin Explosion of this time period. More specifically, varying historical, socioeconomic, and geopolitical trajectories have placed 
Africa and African-based religion and cultural production (via music and theatre) at the center of Cuban national identity. This work intends to explore the experiences of AfroCuban artists based in Miami, Florida, who work in/around the Tropical/Caribbean and Jazz sectors of the Latin Music Industry (LMI) and relevant film and television projects. The breadth of examples presented, through film, music and dance performance, and staged performance spaces reflect hegemony and counter-hegemony in motion.

Although this is not a close study of these sites - the collaboration and collective memory-shadows that are nurtured and nuanced in these sites speak to the multi-layered task at hand for the subversive cultural agent. Memory, in this context, refers to a set of codes or resources that are derived from real and imagined ideas about home (in the case of CubanAmericans) and the place of blackness ${ }^{1}$ in this construction of home. Debates over the usage of memory, abound, specifically in postmodernist discourse, may locate the concept in opposition to the omissions of historical work, i.e. Foucault's discussion of countermemory. As a theory of hegemony and a source of resistance, memory is a site of power relations. In this study, it functions as field-less site for contextualizing cultural production. It participates in a discourse of play with the image of the Other, as a tool for negotiating the labor of black Cuban artists.

Thus, memory, is to be understood as a function of capitalistic and hegemonic power. Approaching the concept in this way, I am proposing more complex considerations of how

Politically, the term 'Black' is linked essentially and primarily with a vision of a (Pan-Africanist) Black World which exists both in Africa and in the diaspora. But "Blackness" is a color-coded, politically-based term of marking and definition which only has meaning when questions of racial difference and, in particular, white supremacy are deployed." (Boyce Davies 7) 
memory and nostalgia ${ }^{2}$ work for the Other of the Other. By this, I mean to draw attention to the way black Cubans, as Other, are strategically employed into the trope of Cubanidad. This trope is paramount to the process by which white Cubans, negotiate movement from the margins to a "safer" space for assimilation and acceptance in the United States.

Black-African identity occupies a marginal position in the racial/social order as defined by U.S. racism and like Western thought. The value of black identity, as leverage for social mobility in the United States, is paradoxical as it is central/marginal to modernity and social status. The ways in which the black body enters Cubanidad, then, is highly mediated by a tailored memory. This memory denies the lived experiences of black Cuban peoples or compartmentalizes (via the arts, food, and religion) the depth of AfroCuban centricity to Cuban identity. As a site for resistance, oppression, and a function of nostalgia, memory can not only misrepresent history, but also infuse environments that are designed to inculcate a specific trajectory. This interpretation of memory is capable of nurturing and even normalizing a distorted truth that becomes collective through dominant ideologies and practices. In this same setting, shadow is employed to metaphor images of blackness in cinema, dance, theatre, and music that have dictated the breadth and depth of AfroCuban and black Latino representation.

Shadow, as used here, gathers momentum from Sylvia Wynter's study of objectivity and a history of compromised, manufactured story-telling that has shaped what the generic

A note on nostalgia: The language used here to describe longing and the materialization of this longing in a capitalist society is deliberately rooted in Western thought. Pointedly, this term is employed to signify the complexity of this industry as it relates to ideas about time, capital, and authenticity. The etymology of the word reveals its history in psychoanalysis. "Nostalgia is from the Greek nostos, to return home, and algia, a painful condition - thus, a painful yearning to return home." (Davis 1) Contemporary usage reflects a more complex process that, in this study, incorporates Othering, notions on authenticity, and the context for nostalgia as defined by an immigrant and/or exile community. 
Western "we" has accepted as fact and thus unmediated truth. Her genius is evident as she challenges the Columbus fable and "untouchable" myths that shape ontological and etymological perspectives and the very creation of such methods of thinking.

Just as the new Cartesian algebra permitted the construction of theoretical physics, so too an original handling of the word can make possible at any moment a new theoretical and needless science that poetry could already give an approximate notion of then the time will come again when the study of the word will condition the study of nature. But at this juncture we are still in the shadows. (Wynter 163)

From said shadows, subaltern identities have/are/will produce nascent entities that we have not yet seen or fail to recognize as perspicuously resurgent. Either way we risk the danger of being blinded by the inability to imagine the transition or remain immune to the dynamics of said resurgence and re-articulation. Emerging from both perspectives is the need to unpack the language and the models that create shadowing moments of hegemonic exclusivity by deflection.

Wynter provokes questioning of the present moment and contemporary participation in meta-stories or meta-fables that serve imperialism, hegemony, and its counterparts. We may ask: Are we at the juncture of the image? Where/how is memory shadowing reality and thus shadowed in the myth of objective science and unobtrusive fables (i.e., marketing and sales strategies)? In this attempt to create alternative modes of thinking, doing, and being, we must question the very understanding of thinking-doing-being that is saturated in myths of origin and myths of history which parallel the intelligence of the Columbus (discovery) fable, and other like-minded adaptive truths. Such fables are directly linked to the meaning that we give ourselves and the ways certain modes of blackness have and continue to dominate expectations of what and who "black people" are capable of being/doing. 
Jointly, memory-shadow suggests a hegemonic, fixed continuum of instructive visual and aural scripts (or stereotypes) that inform, distort, and/or eclipse the lived experiences of black cultural agents. I want here to assert that the mainstreamed image, regardless of its perceived authenticity or acknowledged fabrication, as in fictional work, becomes corporate and by commercialization is stereotype. This point is critical, as the examples used in this paper may be viewed as provincial to a discussion of the realities of AfroCuban identity, as portrayed by popular (sacred and secular) media. Stuart Hall's work on the image (Hall 1996, Hall 1997) supports this discussion through his discourse on the power of the imagerepeated. Emerging questions are: As images repeat, are cultural codes re-constructed? Does the repetition of distorted images support cycles of invisibility?

Repetition and the construction of reproducible images, is in and of itself a process of essentialism and a proponent of institutionalized oppression (i.e., racism, sexism, heterosexism). Thus, as academics, filmmakers, artists, activists, and audiences alike, it is imperative to deconstruct the meaning of images and then re-organize them. This process lends insight for critical viewing and a more conscious, informed practice of watching, presenting, acting, and analyzing.

The study of representations and the overarching field of mass-mainstream media, is full of possibilities for intercultural learning and advancement. Contextualizing representations in the mainstream, through a history of oppression, reveals the subaltern-ized artist's struggle with memory-shadows or reproducible stereotypes. Drawing from the observations of George Lipsitz:

...the ever-expanding influence, reach, and scope of the mass media has worked insidiously to legitimize exploitative social hierarchies, to colonize the body as a site of capital accumulation, and to inculcate within us the idea that consumer desire is the logical center of human existence. (vii) 
"Consumer desire" and the resulting images that overwhelm mainstream mass media often result in/from the internalized racism of an Other. This happens in many Hispanic owned and directed productions that, as the excerpt from Wendell Osborne suggests, marginalizes groups within groups. This project oscillates between the static or fixed inclusion of black Cuban culture and cultural agents in U.S. mainstream entertainment industries and subsets or offsets of this industry that are classified as Hispanic media. It is here, in limited but critical moments of oppression, that ideologies of the dominant Other (white Cuban, anti-black rhetoric) maintains processes of exclusion or fixedness.

The purpose of this study is to facilitate a discussion of the experiences of AfroCuban performance artists and the climate for production given the aforementioned dynamics of mass media. These experiences are directed by a study of transnational structures for cultural production (including the more recent memory-shadow of hip-hop culture in Cuba) and discourse that engages theories of modernity, authenticity, and resistance. The text is mapped out into a story that begins with a brief overview of key memory-shadows in the legacy of the AfroCuban image as it has been promulgated and filtered through Cuba, Cuba's migrants, and U.S. based interpretations of blackness. Chapter one deals with AfroCubanidad as a metalanguage that factors into contemporary U.S. media culture and perceptions of the Other.

The relationship between trends in Latin Music and Entertainment Industries (via the United States and Cuba), U.S. mainstream film, and the preservation/promulgation of fixed images, directs our discussion in chapter two. Here too, I briefly address the ontology of the image, as it exists through theories of blackness, Cubanidad or Cubanness, and Otherness in comparable visual, audio, and written texts. The third chapter deals with the climate for 
cultural production in Miami based upon identified venues and self-identified AfroCuban performance artists. Engaging the artist, we will look at how images have migrated with a people and been compromised, subverted, and deployed at the intersections of Cubanidad as a Cuban ideological process, a projected U.S. construction, and a corporate symbol.

This study is significant because the experiences of performance artists and the process by which they claim space are telling of the socioeconomic, political, and ethnoreligious climate of a given place. Based upon interviews with artists and Industry representatives, the text examines the complexities of this climate. In addition, the pervasive absence of AfroCuban identities in Latin media perpetuates a skewed reality. Therefore, the work of black Cubans claiming/creating space in Miami's artistic communities is timely and relevant to work that seeks to link investigations in popular culture, politics, and interpellation with African diaspora and Latino/Latin American studies.

Debates in the field of AfroCuban cultural studies tend to be insular, primarily amongst Cubanists, musicologists, historians, and theologians. Most venture only briefly to discuss AfroCuban performance artists in the United States, the work they produce, the spaces they work in, or the communities they forge within the Arts. Aside from articles on prominent figures such as Celia Cruz, there are few groupings of thematically familiar texts on the experiences of AfroCuban performers outside of Cuba. There are even less that undertake projects in a contemporary Miami-referenced context. As we will see, the work of Robin Moore on the music and musicians of Afrocubanismo, Arlene Dávila on Hispanic media and marketing, and Katherine Hagedorn on Santería as commodity and capital, are representative of the leading ideas for this study. They are linked by questions of nostalgia, authenticity, mainstream, mnemonic capital, and commodified identity. By discipline, the 
interventions prove helpful in establishing methodological perspectives through ethnohistoric images, ethnomusicological data, and mytho-religious contexts, respectively.

\section{The Field - Miami and Nostalgia}

Miami, as a cultural setting, participates in what I term the Industry of (Collective $\left.{ }^{3}\right)$ Nostalgia. “...contemporary nostalgia is...[a] very big business...thousands of firms exist dedicated to preserving, propagating, and deriving income from some slice of the recent past about which people feel or can be made to feel nostalgic" (Davis 118). Although not exclusively North American, nostalgia as capital, easily fits into the scope of imperialist and capitalist U.S. projects. Expanding Davis' work on collective versus private nostalgia, it has been my observation that this Miami-based Industry of Nostalgia draws from the private experiences of a specific sector of the Cuban population and is promulgated as collective. In Miami, the business thrives through nightclubs, restaurants, festivals/events, politics, and the neighborhood of Little Havana. It positions patrons, residents, and tourists into the stratification of its operations. In fact, initial observations quite overtly outlined nostalgia as a primary element given the names of certain businesses (i.e. Café Nostalgia).

Today, persons born in Cuba or of Cuban descent represent Miami's Largest ethnic group. During the 1960s their concentrated settlement pattern gave the name of Little Havana to a portion of $8^{\text {th }}$ street near downtown Miami... The "Cubanness" of the city is manifested not only in

Collective nostalgia, refers to that condition in which the symbolic objects are of highly public, widely shared, and familiar character... private nostalgia refers to those symbolic images and allusions from the past that by virtue of their source in a particular person's biography tend to be more idiosyncratic, individuated, and particularistic in their reference... (Davis 122-23) 
demonstrable terms, such as economic activities and cultural events, but also in a more intangible manner, such as "ambiance."

(Grenier and Perez 47-48)

Miami as a home base for this project is ideal in its demographics and relationship to the construction of U.S. based Cubanidad. This intangible "ambiance" identified through the Industry of Nostalgia, reflects preoccupations with creating social settings, theatrical productions and/or music and dance genres that reinvent and re-imagine home. Little Havana localizes Cubanidad and the sentiment of some Cuban immigrants through the crafts, performances/events, dining opportunities, and artistic displays that characterize dominant representations of nostalgia a la Miami-Cuban cultural expression. It serves a longing for "the way things were," a legacy of cultural traditions, and aesthetically familiar spaces. As discussed by Grenier and Perez, this longing is part of a larger discourse of exile ideology that seeks "recovery" of Cuba, as opposed to return.

We have been careful...to use the phrase 'recovery of' the homeland and not 'return to' to describe the exile ideology. The former is the abiding interest in seeing the homeland out of the hands of Castro government. Returning is something else, especially if a large portion of the exile generation has already passed away in the United States. (I20)

Within this recovery of land is the maintenance/preservation of certain imaginations of culture and identity. Establishing a new (transnational) identity in the United States, based on the memory of Cuba-then (nostalgia) is a primary project. The ways in which AfroCuban images and black Cuban artists figure into the ideology of the recovery "process" is of interest to this study.

Nostalgia, centralized through memory, ideology, and capital, is often overtly sensational as it manifests in the structural, political, and artistic environment of Miami. As previously mention, nostalgia is highly visible. It is primarily deployed through thematic 
spaces such as Café Nostalgia and Hoy Como Ayer which double as restaurants and dance clubs. Another important site is Calle Ocho or $8^{\text {th }}$ street, which is full of testaments to Cuban culture via Cuban (-American) personalities, cuisine, arts, religion, and lifestyles.

The positioning of AfroCubans, the virtual absence of other Miamians (i.e. Haitians and African-Americans), the varied meanings of Cuban whiteness in relation to white Anglos, and the financial and nationalist support of white Cubans make up the oppressive, essentialist, and counter-productive dynamics of the Industry of Nostalgia.

Given this racially and ethnically stratified climate, it is necessary to identify, briefly, the cognitive semantics of whiteness/blackness in Miami. Historically, the politics surrounding the initial influx of Cuban exiles into South Florida incited fear.

...[the] native white community was concerned largely with preserving its own life-style; it had little inclination to go poking into the complexities of foreign policy...For Washington, the Miami exiles were not an 'ethnic' group, but an important ally in the fight [against Castro/communism] for Cuba and Latin America. (Portes and Stepick 29)

Juxtaposed with then contemporary and subsequent relationships to the Other, as white Cuban/ black Cuban/black Caribbean (notably black Haitian)/black American, the layers of marginality were reconfigured with time and new migration patterns. The meaning of language, identity, complexion, gender, and politics as a federal project favoring white/light skin and a local project fearing any Other (in relation to white Anglo identity) lead us to the current moment that is an intricately webbed matrix of Cuba/U.S./South Florida racisms, political machines, guarded economic thresholds, and cultural projects.

Within Miami-Dade County, white-skin is interpreted differently in its Anglophone and Hispanophone systems of operation. White Cubans of middle to upper economic backgrounds act upon privilege that is awarded and/or assumed by white Anglos. Acting as 
middle managers with segments of economic (income not wealth), cultural, and political control, the beneficiaries of this system are predominately white Cubans. According to the 2000 Census approximately 2.2 percent of Hispanics in South Florida identify as black (FIU/Cuba Poll 2000, Census 2000). This statistic is based on self-identification. Many black Cubans do not identify as black given the varied and stigmatized meanings of blackness in the United States. Identifying in this way may be perceived as a limited signification of AfroCuban identity. Nevertheless, it is a relevant and necessary consideration.

Despite the presence of black Cubans in Miami, they are virtually absent from upper/middle strata neighborhoods in areas such as Kendall, Coral Gables, Hialeah, and the beaches. Many live on the outskirts of these municipalities and in the middle/lower strata of traditionally African-American neighborhoods, such as Carol City, as well as sections of Hialeah. Few live in Little Havana, which is predominately white Cuban. Although living in the neighborhood does not imply status, with the exception (perhaps) of artists and spiritual teachers/leaders, most Cubans respect Little Havana as an important symbol of CubanAmerican culture.

Aside from the popular business, Havana To Go, which is owned by AfricanAmerican entrepreneur, Carol Taylor, the establishments lining Calle Ocho are predominately owned by white Cubans or white Anglos. The street is full of white Cuban/white Latino aesthetic. from record stores to art galleries to community centers. AfroCubans and symbols of AfroCuban culture are absent, however, save representations of Orishas that adorn the storefronts of Botanicas. Several attempts to create cultural spaces that more accurately display the many ethnicities and cultures of Cuba have been met with resistance. As a result of these obstacles many AfroCubans express little or no desire to 
attend events or frequent establishments in the area.. The resistance of white Cubans is perhaps best outlined through examples of how memory-shadows, negative perceptions of AfroCuban culture, little support for AfroCuban cultural events, and relationships between black and white Cubans embody prevailing rhetoric and ideology.

The pedagogical approach to Cuban studies, through dance, as described by Nadine

Fernández in her occasional paper, "Teaching Cuban Identity in Miami through Dance: White Hispanic vs. AfroLatin," demonstrates the complexities of white/light CubanAmerican perspectives on AfroCuban culture. As part of the Dancing Across Disciplines program at Florida International University, Fernández incorporated Orisha dance and guaguancó into the traditional lecture/discussion format of the class on Cuban culture. Looking at identity through the arts enforced the importance of cultural production to identity construction and revealed the persistence of a discourse that has systematically erased or demonized black Cuban identities and AfroCuban culture.
Although there are over 10,000 black Cubans living in Miami and they have been part of every wave of Cuban immigration to the US, the majority of the exiles can be classified as white (in the Cuban racial designations). My Cuban students don't think of themselves as being part of a multiracial group, or of being from a country with a highly racially mixed population. Cubans want to continue to be a 'model minority,' - a white minority - and even black Cubans in the US seek to distance themselves from the marginalized African-Americans and in Miami from the even more stigmatized Haitians. (Fernández 2003)

The reactions of Fernández's students confirm how racism and aspirations for assimilation (by white/light "Hispanic" Cubans) depend upon the marginalization of blackness via AfroCubans and AfroCuban culture in the United States.

How does this translate to the work available to black Cuban cultural agents? During festivals held in Little Havana such as the monthly celebration, Viernes Culturales (Cultural 
Fridays), the sidewalks are lined with vendors selling crafts, paintings, and food. Music can be heard on the corner of each block. Although primarily recorded music, there are a few live bands that attract small groups from the crowd of hundreds. It is here that certain AfroCuban musicians and vocalists will find work playing pre-revolutionary or non-spiritual/traditional music, similar in style to the Buena Vista Social Club. When visiting these festivals it became evident that the only black Cubans present were participating in a staged performance.

From time to time galleries will incorporate Orisha artwork, invoking representations of black-African culture. On a given night, one may find a theatrical production in the generic $^{+}$venues of Little Havana such as the Manuel Artime Theater. Unfortunately, there is a tendency of low attendance. Likewise, certain gallery shows have generated comments that Black Art is "too ethnic" for the average audience (read white Cubans and white Anglos). 1 have also observed flyers and posters promoting AfroCuban events or artists being defaced, ripped apart, or strewn about sidewalks and dumpsters. Although rare, this behavior provides practical and psychological challenges for black Cuban artists, many of whom are investing time, limited funds, and energy in marketing and promotions. Primarily, marketing and attendance are serious challenges for new or up and coming artists who are not part of an established group or endorsed by a white Cuban/white Latino company or organization. This is a reality that we will revisit in chapter three through the statements of artists and producers.

"Generic," here, refers to a venue that is not specifically themed with Cuban nostalgia (i.e., Hoy Como Ayer). Instead it is a space where the ambiance is transformed by the specific performance or event taking place. 
As the meaning/representations of culture are reshaped by people and cultures crossing borders, relationships between black and white Cubans change as well. Further cues for understanding the complexities of Miami and the climate of/for color stratification were exposed in the momentous article, "Best Friends, Worlds Apart" (Ojito 2000). Through interviews with two Cuban men, the reader is presented with several principles of U.S. racial stratifications as they intersect with Cuban ideologies (re)creating a new social order within Miami. The story chronicles the friendship of a Joel Ruiz who is black and Achmed Valdés who is white. The two are friends in Cuba and diverge as they begin their new lives in Miami.

Revealing moments in the article are when Valdés describes difference-realized, a process marked by his re-socialization in the United States: "It's not that I'm racist... But even in Cuba, I had a vague sense blacks were different. That becomes more real here. In Cuba, everybody's the same, because everybody's poor. Not so here" (Ojito 2000). Contrary to popular rhetoric that denies or qualifies Cuban racist ideologies, the article realigns prerevolutionary perceptions with the racial politics of the United States as experienced in Miami.

Ruiz was somewhat shocked with the rationale of his old friend. The cruelty of the transmogrified moment is unveiled. Further discussions with Valdés reveal his perceptions about African-Americans who "... are to be avoided because they are delinquent and dangerous and resentful of whites. The only blacks he trusts, he says, are those he knows from Cuba" (Ojito 2000). As it follows, the impact on African diasporic and cross-ethnic, intercultural relationships is immeasurable, as several black Cubans have found AfricanAmericans more receptive than their fellow country persons. 


\section{Theory and Method}

In his essay, "Paul Simon's The Capeman," Alberto Sandoval-Sánchez works through notions of authenticity, Latinidad, and staged performances as he unpacks the dynamics of the 1997 Broadway play. "It is only when we take into consideration how Latino Otherness is registered within the Anglo sociocultural imaginary that the issue of racism can be fairly tackled" (Hábell-Pallan and Romero149). Although Sandoval-Sánchez appropriately explicates constructs of Latino/a Otherness, we must also insert a discussion of how Latino Otherness and black Otherness are often perceived as mutually exclusive. As such, the dynamics of Afro-Latin(o) realities necessitate a central space in current creativeintellectual arenas.

In order to navigate the sinuous character of this study, the project gathers momentum and direction. from a variety of informants and has been conceived through a theoretical mosaic. The organization of the thesis draws heavily from the concept of Unicentricity as discussed by Carole Boyce Davies in her article, "Beyond Unicentricity: Transcultural Black Presences.” Boyce Davies defines “...Unicentricity as OneCenteredness, a logic which demands a single center (intellectual, economic, political, cultural, geographic) from which all emanates" (96). I have, therefore, employed a relevant, though complex, collection of theoretical and methodological choices. Using this approach, I intend to avoid a unicentric discourse that negates the complexities of the subject matter and the interconnectedness of many sociocultural, hegemonic and subversive media projects.

This work deliberately positions ethnographic fieldwork in a non-linear, continuum of theories that reflect the pedagogical lean of African diaspora studies and the interdisciplinary, inter-genre scope of cultural production. Rejecting conventional academic 
work that locks studies into potentially limiting discourse, the framework incorporates the interventions of scholars/artists/activists such as: Coco Fusco, Stuart Hall, Abdias do Nascimento, Sylvia Wynter, and Mircea Eliade. This work builds on these scholars, addressing the politics of interpellation, re-presentation, and resistance, in terms of the cultural capital of Miami, as a specific geographical place and as a conceptual space.

This research is qualitative in nature, in that concepts of Cubanidad, blackness, memory, and nostalgia, may be best understood through participant observation, conversational interviews, surveying social spaces, and library research (including research of local newspaper and magazine articles). Research was conducted in four specific avenues of learning: venues, formal/informal Latin Music Industry sectors, U.S. commercial film and television projects, and the experiences of artists, producers, and mangers. In addition, qualitative research methods, as stated above, allowed for observation of the specific and complex ways that social markers operate in the identified contexts. Such markers include, but are not limited to: gender, age, sexuality, sexual preference, perceived physical ability, aesthetic capital, race, ethnicity, nationality, religion, and spirituality.

Venue data was collected and analyzed by focusing on two primary spaces: Cafe Nostalgia and Hoy Como Ayer. Using decor, live performance history, and patron demographics, these venues provided information on how and when AfroCuban artists, real and imagined-imaged, enter thematically Cuban, music, dance, and nightclub scenes. Latin Music and Entertainment Industry data was collected and analyzed by focusing on televised performances, the 2002 Billboard Latin Music Conference, and conversations with Gabe Baptiste, Director of Television - Latin America, Zeal Television USA, Bruno Del Granado, President, Maverick-Latin Division, and Leila Cobo, Chief Editor on Latin American and 
Caribbean Music, Billboard Magazine. This data served as a background for understanding the memory-shadow that engages both local and global artistic spaces. U.S. Mainstream Film data resulted from the observation of scenes from the films: "Buena Vista Social Club," "Dance With Me," "Before Night Falls," and "For Love or Country: The Arturo Sandoval Story." Artists, producers, and managers supported this project through interviews and the observation of business practices, logistics, and live performances.

\section{Playing Miami: AfroCuban Performance Artists Negotiating Cubanidad, speaks to}

gaps in Afro-Diaspora, Afro-Latino/Hispanic and relevant cultural studies. As the field expands, new language is developing to articulate what Tanya Katerí Hernández identifies as a situation where, "Afro-Latino/as are often positioned as equally foreign as Anglo-Blacks to the portrait of authentic Latino/a identity" (153 2003). Yet, in certain functions of Latinidad, as Cubanidad, the paradox of the Other in the construction of the self is paramount through the central-marginal-central positioning of blackness in Cuban (trans)-national identity politics. As such, the Afrocubanismo of Robin Moore's 1920-1940 study resurfaces through contemporary patterns of denial and acceptance. Afrocubanismo in this period locates personalities, institutions, cultural tools, and social ideologies of AfroCuban culture as "...both powerful icons to rally behind and markers of degeneracy, reminders of a cultural legacy most considered shameful"(220).

Several theorists, too numerous to mention here, have created frameworks for locating black identities and racial stratification in/amongst Cuban communities in Cuba and to a lesser extent in the United States. This study intends to contribute to a discourse on the specificities of AfroCuban performance within a transnational paradigm of racialization and cultural production that intermingle with and are imbedded within forms of racism and 
ethnocentricity that operate within, but are not solely characterized by the United States, in general, and by Miami in particular.

The experiences of interviewed artists are also interwoven with a voice that works through my own experiences as an Afro-Caribbean, black-American woman, born and raised in the northeast United States. Landing somewhere between reflexivity and autoethnography, my self-made and contextually interpellated identity has largely affected access and subject-placement in various social settings. As such, the realities of studying, living, and working in the field have been a source of great insight and frustration. I often found myself attempting to discern constructive criticism from a resistance that is rooted in the belief systems of classmates and colleagues. Many, I would soon discover, subscribed to a rhetoric of denial in regards to racism in Cuba and the extension of said racisms in Miami amongst Cubans and Cuban-Americans. 


\section{Imaging the Other: Memory-Shadows and the Image}

This chapter advances several theoretical interventions to approach the following questions: What are some critical ontological considerations for discourse on differentiation and Othering? How has the positioning of "blackness" as "Other" in (historically informed) contemporary media culture influenced or maintained white/light notions of Cubanidad? How then, has "blackness," as folkloric or authentic, been reconciled as a necessary factor in U.S. Cubanidad? How has the religious aspect of AfroCuban culture been figured into the perception of the Other? The language of differentiation, and contextualizing cues from the famous opera "Cecilia Valdés," pre-revolutionary theatrical images, and Santería-derived cultural production, initiate the dialogue. Identifying relevant memory-shadows, this chapter attempts to facilitate a discussion of cyclical patterns of marginalization and mystification, which mark the AfroCuban cultural agent.

\section{$\sim$ Differentiation and 'Othering'}

The semiotics of difference is of primary interest for those preoccupied with the racialization and/or ethnicization of an individual or a group. The function of difference as a social construction provides an arena of ideological informed, object/subject readings of normality, belonging, and identity. Such readings manifest in the desire, ability, and necessity to acknowledge that there is something lacking in you, on you, about you that is not lacking in the dominant $I$. Perhaps then it can be said that difference is constructed out of 
fear of the loss of individuality. The use of this initial differentiation to remedy or dismiss the Other manufactures social scripts or codes of behavior. Birthing replications of its original form it manifests as ideology, often becoming normalized and even internalized by the "Other."

It should be noted that in the context of race and ethnicity studies, the relationship between the constructed notions of private and public is fundamental. This dyad, which appears in many forms (i.e. insider/outsider), locates authority, definition, and agency. Referencing nationalism, Gilroy identifies this dyad through a discussion of "cultural insiderism." "The essential trademark of cultural insiderism which also supplies the key to its popularity is an absolute sense of ethnic difference" (Gilroy 3). From this linguistic/semiotic reading of the dyad, we derive the language of a coded difference that affects the experiences and/or identities of persons in two critical ways. One role of difference is to create dividers, the public insider/outsider dialogue, in which the objectification of the outsider, in what is deemed public and/or dominant space, sustains the identity role of the insider. The performed arts exemplify this in its potentially constitutive forms that may be culturally specific (i.e. nostalgia in Miami) and those that are promoted as having "generic" consumer appeal (i.e. U.S. mass media markets).

Verbalized physical acknowledgment of the identity-subject relationship in differentiation is paramount, as it is defined in the ominous absence of the Other. Positioning the Other permits self-definition. The ability to act as a spectator in difference gives way to a language of vocalized distance in (metaphysical) measures of proximity. The ability to objectify the subject through language is a tool for positioning. The use of the word "look", for example, in Frantz Fanon's description of a young boy saying to his mother "Look a 
nigger" communicates this exchange (Fanon 114-115). Look meaning look at, look to, and look there, implies something momentarily critical to, yet outside of, ones being and/or experience.

In defining the self, one may locate the space that one occupies, i.e. social status. This positioning may also inform who has priority over the other to exist first (read authoritative voice) and be an agent in modernity. Locating the importance of time (as progression) as it facilitated by the phylogenies of "primitive" cultures, allow for a more immediate assessment of the relationship of time and space to hegemony. When the primary or dominant subject has been established, the Other is allowed to coexist within a specific framework, i.e. social scripts. The institutionalized articulation of "look at blank" creates naturalized ideologies of the self, through xenophobic representations of what dominant culture is and what space it occupies in relation to the culture of the Other.

Authority over such claims (of dominant space) rewards influence of, if not primary ownership over, academia, media, the arts, and like genres, as these fields often interpret, reproduce, and perpetuate the legitimization/authentication of experience and belonging. Although culture is constantly changing, it is often promoted as a stagnant informant of societal behavior and historical continuity. As such, there is a resulting indoctrination of an ideal - light/white-skin oriented - cultural identity in Cubanidad for which all Cubans should strive. The extent to which Otherness operates in Cubanidad, in relation to the marked of the marked (Other of the Other), is realized in the way the qualities of the marked (African identity) is mediated, whereas the unmarked qualities (white Hispanic identity) is encouraged to prevail as the totality of the collective self (Cuban national identity) in public spheres. "Maintaining the white (and successful) image of the Cuban exile community is a major 
priority for the exiles...Are Miami Cubans ready to risk their position as the "model minority' [read the model Other] by having a black face represent their organizations...?" (Fernández, "Miami Cubans in Black and White," 10) This observation illustrates desires to surpass difference (read assimilate) and the myth of the model ethnic group or individual who must deny their markedness, unless it is of particular non-generic value, i.e. folklore. Edward Said in similar ways to Frantz Fanon engages new understandings of the ways in which humans negotiate identity politics. Fanon introduces the consideration that "All forms of exploitation are the same because all of them are applied against the same object" (Fanon 88). Within this context, Fanon's concept that the body defines the being and the body is defined from the outside is strikingly familiar to Said's statements, which claim that the Orient defines the people and the Orient is defined by the West. Akin to concepts of what is the Orient, Fanon's interpretation of the perceptions of the "soul of the black" is a creation or artifact of the white man. In Fanon's text he presents the concept of two camps, that of the black and that of the white. In debunking the myths of Orientalism, Said states that, "it [Orientalism] not only creates but also maintains; it is rather than expresses, a certain will or intention to understand, in some cases to control, manipulate, even to incorporate, what is a manifestly different....World (Said 12). Orientalism, like most systems of essentialism, demands (is), rather than asks (expresses) a need for understanding or knowledge. It is this very structure of Orientalism that links it to other forms of domination and exclusion, such as Cubanidad.

In the tradition of Glissant, Fanon, and endless intellectuals, the work at hand identifies the self and Other dyad, as a function of fascination and exotification, orienting ideologies, which romanticize and/or homogenize the Other. "The Orient was almost a 
European invention.... A place of romance, exotic beings..." (Said 1). This "Orient" reconfigured can also be applied to the case of AfroCuba and the meanings of African culture and peoples in a white Cuban context. As Moore eloquently mapped out, the co-optation of African culture (specifically religion and music) contributed to maintenance of superior roles based on practicality and intelligence. These are attributes that, as the trope goes, are lacking in the AfroCuban, i.e. the case of the tragic mulata.

Positioning the Other in a trajectory of popular music and authenticity, as expressed in the subsequent quote from Maverick Latin (a new division of Madonna's Maverick label) President, Bruno Del Granado, speaks to how and when the foreign body enters the dominant schema. In terms of profit driven industries there is a constant search for what can be packaged and mass-produced in tolerable dosages for the "general" public. According to Del Granado this general public is one that finds Latin culture exciting and is specifically Western by way of the United States.

Every couple of years, the mainstream market wakes up and realizes that a large percentage of our population is of Latin heritage and it's time to pay attention to them. Up until last year, the regular Grammys had been boring... So everyone is waiting for the next big thing, and then Ricky Martin gets on stage, shakes his hips and does a tremendous rendition of a song that had been a number-one hit in $4 \mathrm{I}$ countries, La Copa de la Vida. The world falls in love with Ricky, and all credit to him, he's a tremendous showman... Americans like to feel exotic...[and] the next morning, [after Martin's Grammy performance] I got about 50 calls from American Anglos asking me, How do we get to Ricky Martin? We want to offer him this, this and this... But as is the case with everything in the United States there was so much media overkill the artists started shying away from that whole thing. - Bruno Del Granado (Sutter)

This level of exoticism fuels the industry as a whole and sustains the repeating language of self-identification/interpellation conflicts. On the level of discourse, this Latin Phenomenon can be examined through Fanon's interventions in exotica studies. Linking 
perceptions of Latino identity with that of the "Negro" Other, this level of engagement becomes a substantive point of departure for looking at the perceptions of the white man in his evaluation of Negro creativity. Quoting a friend, Fanon communicates, "When the whites feel that they have become too mechanized, they turn to the men of color and ask them for a little human sustenance" (Fanon 129). With this Fanon is excited by the thought that whites could find him valuable. Later discoveries, however, lead him to the irony of essentialism. "The man explained to me that genetically, I represented a stage of development. My originality had been torn out of me" (Fanon 129). This reveals the true control that a dominant culture may have, for when they create characteristics within their Other, they claim agency to regulating the extent to which the Other is accredited for their talents or special attributes.

Also asserted is a control which limits they way the image of the Other is distributed. Often this plays out as specific representations of color (white/light), a hypersexual twogender model (negating identities that work outside of the male/female binary), and sexual preference (heterosexual). Likewise, originality, specifically creative labor, creates complex paradigms. In a profession that has been largely dominated by images that ridicule, idealize, and denigrate the black body, it is a challenging for black cultural agents to negotiate loyalty to their projects and the realities of surviving as working artists. For many artists, negotiating the myths of Cubanidad and resulting representations in local (Miami) and global mainstream media have confirmed a historically familiar pattern.

Historically, the visualization of a mythic essence and accompanying race ideologies have been present in literature, musicals, and operas such as "Cecilia Valdés." In its contemporary absence/presence, the AfroCuban male/female image is rooted deeply in the 
language, politics, and nationalizing ideologies of Cuban identity. Similar to the characters of the minstrel show (Sambo, Mammy, Jezebel), AfroCubans have generally been marked as dancers (dark-skin men), musicians and vocalists (dark and light-skin men), folkloric dancers (dark and light-skin women), seductive (light-skin women), and spiritual dancers (dark and light-skin women). Each of these categories or contested images at some juncture-of-theimage has overwhelmed representations of blackness in Cuban literature and performance.

The selected examples of AfroCubans in literature and the performing arts reflect the cognitive template or consciousness of important moments in Cuban society. Cecilia Valdés remains one of the most recognizable historical figures. The text, which then became an opera, was written by Cirilo Villaverede in 1839 more than thirty years before the abolition of slavery in Cuba. The opera, composed and originally conducted by Gonzalo Roig was released in the early twentieth-century, and first performed in 1932 at the Teatro Marti in Havana. At the creation and release moments of Cecilia Valdés, white Cuban society was seeking ways to reconcile its black/African population, nationalism, and ideologies of morality.

...in the early twentieth century, Americanization was resisted through the celebration of the 'Latin race,' by the 1920s an autochthonous culture was increasingly understood as the fusion of the white and black elements that had produced a synthesis deemed to be uniquely Cuban... Through the rhetorical exaltation of cultural and racial miscegenation, the emergent discourse of cubanidad, which found in the Afrocubanista cultural movement its most visible expression, challenged dominant conceptions of blacks' inferiority and the negative effects of racial mixing. (de la Fuente 178)

The story of Valdés chronicles the seductive allure of the mulata and her tragic state as exotic yet impure and incapable of having a lasting relationship with a "full-blooded" white Spaniard (Leonardo) who is also her half-brother. Born to an enslaved black woman, 
Cecilia is undone by the attention of Leonardo who "falls in love" with her beauty and vows to be dedicated to her alone. In the end, she is betrayed and abandoned. She is desirable in her near-whiteness, displaced by her blackness, and made perverse by her desire for her halfbrother. Cecilia's mother, who was formerly enslaved, is portrayed as a helpless, poor, and inarticulate black woman. Her song "Tango Congo Po Po Po" in its structure and lyric suggest her inadequate education and inability to secure financial and emotional stability, reflecting a legacy of social scripts applied to dark-skin black Cubans.

Cecilia is "unaware" of her true identity as the daughter of a rich Spaniard and is carried by her stunning beauty and seductive appeal alone. Although she finds love with Leonardo, it is temporary and his affections turn to Isabel, an "upper-class" respectable woman. Soon after, it is discovered that Cecilia is pregnant with Leonardo's child. She is driven to madness by the events that have transpired. lronically, she is placed in an insane asylum and it is there that she is reunited with her mother. The opera ends with Cecilia singing: "Virgen santa, Virgen Buena -- Cecilia Valdés pecó, pero Cristo perdonó -- un dia a la Magdalena por un pecado de amor." Valdés confesses that she has sinned for love and asks for forgiveness. Leonardo is redeemed through his marriage and ultimately his death (at the hands of Cecilia's black admirer) and Cecilia becomes perverse and cursed in life.

This formula exemplifies a social script of the tragic mulata and the perception how blackness determines one's fate and one's ability to exist as a sane, active, and/or productive member of society. To date, the opera remains a national treasure and through its mainstreamed international popularity, projects a tradition of normalized white Cuban identity and hypersexual, mystic, and/or inferior black Cuban identity. The mainstreamed 
image, as in this fictional work, both constructs and maintains the stereotype. The opera is a testimony to the rhetoric of attempts to deny African people's agency, value, and importance.

Minstrel productions of a similar era sensationalized the black body as a spectacle and created a parody of black identities. They were grotesque representations of AfroCubans and the music and dance associated with AfroCuban culture. These productions eventually led to the popularity of "AfroCuban" music through the interpretation of whites and consumerism by white Cubans of primarily middle to upper economic status. In Nationalizing Blackness: Afrocubanismo and Artistic Revolution in Havana, 1920-1940, Robin Moore provides a historical argument for the crucial role of cultural production in comprehending ethnicity and the commercialization of subaltern cultural agents. He supports this argument by identifying the paradoxical marginalization of AfroCuban artists during the 1920s-1940s in Havana.

The text is committed to the necessary, detailed account of musical expressions and incorporates theoretical analysis throughout the history of specific Cuban musical, theatrical, and literary genres. The focus of the work is to "demonstrate the numerous ways that musical production not only 'reflects' social inequalities, but is itself a means by which racial tension, economic exploitation, and dominant political discourses are perpetuated or manifested" (Moore 219). Here we are cued to the cyclical pattern (in pre and postrevolutionary moments) of the interconnectedness of social markers (race, color, class, gender) and processes of cultural production and consumption.

Moore makes the claim that there are identifiable groups that have brought AfroCuban music to the national forefront. Approaching the polarities of ethnicity and agency, the groups are identified as: 
Professional, conservatory-trained musicians and other members of the (typically) Cuban 'culture elite' [who] created representations of blacks and black music 'from above' that had a tremendous impact on commercial and noncommercial production in theatres, symphony halls, motion picture soundtracks, nightclubs, cabarets, and published sheet music...[The second group being]...working-class and underclass AfroCuban performers [who] affected music making on a national level by forming carnival bands, popularizing syncretic genres such as the son, performing music and dance for tourists, and perpetuating more directly African-derived musical traditions associated with traditional rumba and santería ritual. (Moore 5-6)

Within this relationship, "Africa" is re-centered as a critical component in the national identity of Cuba. At the same time, AfroCubans became increasingly marginalized through the effects of tourism, a history of misrepresentation, and a lack of meaningful political incorporation. Further cues to the legacy of blackness surfaces through the description of typical themes and common characters in the music and dance of the teatro vernáculo (comic theatre). As the genre developed, drawing influences from Spanish, French, and North American theatrical forms, the characters became standardized. Such characters or players ranged from the comic black man, to the mulata to the gallego (Spanish shopkeeperbusinessman).

Moore also provides a four-decade overview of Comparsas (AfroCuban carnival bands), and their gradual acceptance as a form of Cuban national expression (Moore 63) Comparsas proved vital to the visual self-representation of AfroCubans and AfroCuban culture. Through the entertainment and political significance of son music, he advances the argument. Although son music can be defined in a variety of ways, the lyrics are most often in Spanish, employ European-derived poetic forms such as coplas, cuartetas, and decímas, and sometimes include "African" terminology (Moore 90). Often one would find AfroCubans using son and other accepted musical forms to incorporate lyrics influenced by 
Santería. For example, song titles such as "Papa Oggùn" (Father Oggùn) and "Canto lucumí” (Yoruba chant) were used by sonero and rumbero Ignacio Piñeiro.

Through a discussion of radio and recordings. Moore illustrates the anxiety that existed during the rising popularity of black working-class music and the values of mostly white, Cuban elites. He offers the following symbolic reality that spoke to the struggle for participation in a growing industry of music and cultural production, given the hostile racial climate: "For the rich, radio (and records) provided the opportunity to listen to AfroCuban popular song without interacting with AfroCubans themselves. Black and mulatto singers who would never have been allowed to enter elite homes and clubs first gained admission over the airwaves" (Moore 103). This history provides a necessary reference for contextualizing the process of contemporary sacred/secular cultural production as understood in the legacy of black Cuban struggles.

The interpretation and influence of African derived religions, here, Santería, advances this discussion in a critical way. AfroCuban religious traditions have fueled many investigations of black Cuban culture, people, and thought. Most notably (although not exclusively) through the work of Fernando Ortiz, images of AfroCubanidad have been wrought with negative interpretations. Although important to the documentation of black identity in Cuba, the early pre-transculturation work of Ortiz maintained theories of criminalization, mythification, and exotification (Hagedorn 191-93).

Even in the midst transculturation, which intended to unite the nation under the premise of an equally important exchange between Spanish and African culture, the memory-shadow of AfroCuban as inferior persists. Countering the source of these ideologies, which largely came from misinterpretations of AfroCuban religious theory and 
practice, is the work of black Cuban performance artists. Black Cuban cultural agents have used their spiritual beliefs and religious culture to negate misrepresentation in the Cuban and U.S. based mainstream imagination. Briefly, we will engage theories and examples of ethnoreligious cultural production to illustrate this intervention as a site of oppression and resistance.

Grounded in Gramscian hegemony, Stuart Hall's deconstruction of the image and discourse on meaning in popular culture, lend well to the dialectical relationship between Mircea Eliade's theory of hierophany ${ }^{5}$ (the manifestation of the sacred in the profane), commercial cultural production, and social interpellation. Informed by Eliade's text, The Sacred and the Profane: The Nature of Religion, we may find language for articulating real/imagined ethnoreligious cultural agents manifest in: the physical body, artistic material (music or dance), and performance space. Given the weight of ethnoreligious meaning in AfroCuban identities and what is often termed AfroCuban music, Eliade provides a departure point for locating the theological perspective of this discussion.

Katherine Hagedorn's Divine Utterances: The Performance of AfroCuban Santería centers on AfroCuban religious/commercial performance and uses the legendary AfroCuban dance troupe and think-tank Conjunto Folklórico as a case study. Through her descriptions of the research-work and performances of Conjunto, Hagedorn problematizes the concept of Cuban folklore, which she states "... has been racialized and disempowered" (Hagedorn 4). By fixing Mircea Eliade's theory of the manifestation of sacred in the profane as an axis mundi, she positions the reader at the heart of AfroCuban ritual performance. She locates

$5 \quad$ Hierophany can also be understood as such: "By manifesting the sacred, any object becomes something else, yet it continues to remain itself, for it continues to participate in its surrounding cosmic milieu." (Eliade 12) 
AfroCuban cultural production and cultural material in a trajectory of Cubanidad that reconciles Africa and subsequently blackness as a necessary, static myth. Using this approach as a departure point, this myth serves as a reference for modernity, locates nationalism, and buffers capitalism by providing a vibrant source for cultural consumerism within the state and abroad.

Hagedorn rightly assess, however, that in spite of this "functional" existence for the sake of nationalism, African-based religions are very much alive and participating in the evolution of both a real and imagined Cuba. As such, groups like Conjunto have always negotiated the dedication to preservation and exchange as well as the foreign gaze, which, through the many dimensions of tourism is a vital source of economic stability and growth. At the same time, their participation in tourism is just one of the many facets of the rapidly expanding business of Santería as a commodity. Employing these useful interventions, we are able to identify aspects of the commodification of AfroCuban social scripts and envision the semantic of blackness in a postmodern, sacred/secular Cubanidad.

Fluid movements in the course of a study such as this rely upon a collaboration of theory and ideas on theoretical interventions from several sources. Drawing parallels in phenomenology, authenticy, folklorization, Othering, and processes of blackness and Cubanness, I intend to make elastic the often-rigid paradigms of Black and Latino studies as mutually exclusive. In her book, Latinos, Inc. The Marketing and Making of a People, Arlene Dávila offers critical interventions for studying new marketing practices by/for Latinos in the United States.

Conducting fieldwork in advertising agencies, her timely research unpacks Latinidad as both identity and cultural capital. She makes the point that "...when black Latinas are 
shown [in television programming or commercial ads] they are mostly media or entertainment personalities like Celia Cruz...black Latinas are seldom signifiers of generic Latinidad" (Dávila 121). Dávila's work provides a space for looking at images in film and music that are both created by and marketed towards Latinos/Hispanics and "generic" or mainstream Anglo markets. Where lacking a significant discussion of the absence/presence of black Latinos in the Entertainment Industry, the next stage of this study intervenes. The departure point, as constructed through literary, musical, and scholarly guides, make available a space for discussing the Latin Music and Entertainment Industry. 
The geographic and marketing/production spaces created through the investment of the Federal government, by way of a national anti-Castro project has provided subsidies for specific growth in the Miami-based Cuban American community. However, as space is allowed to a white/light Cuban aesthetic the parameters of this same space are highly mediated and create incredible obstacles for black Cuban artists and artistic production. Navigating these boundaries, artists, transnational projects (Cuban hip-hop industry), and visual representations of Cubanidad participate in a struggle between the realities of the U.S. based entertainment industry and the shadowing memory of visual/social scripts of blackness as/in localized Cubanidad. In this chapter we will look at the paradox of new realities in music by way of genre fusion and the influence of projects in the most recent Latin "Pop" Explosion as seen through film, formal industry recognition, dominant representations, and the absence/presence of the black body.

The power of images, motion and still, and the establishment of industries based on these images act as an invaluable source for the study of human behavior and thought. The exploration of blackness as used here is grounded in the impact that said images have in a post-industrial, technological age of mass reproduction and repetition. The repetition and/or desire for static images inform the cultural codes that produce (re-construct) and affirm stereotypes, exclusion, and a cycle of invisibility that negates the true diversity of the African diaspora and the Latino population. According to Stuart Hall, stereotypes are often 
approached in a bipolar fashion (Hall 1997). It may be perceived that to improve or balance negative stereotypes one must insert positive stereotypes. However, this serves as a shortterm answer to much more complex questions and intellectually sophisticated approaches.

Leading into this discussion, I assert that characters, images, and re-presentations must be complex, diverse, and have breadth in their depictions in order to begin to subvert the fixed meaning of the stereotype. In this way, we may focus on the agency of the artist (in the midst of misrepresentation) and theories, made through the labor of production, that maintain, reject, and reconstruct images. It is at this level of inquiry where we encounter a language that reverberates from/within the multi-layered theoretical context of the screen image, televised and live staged performance, and the multi-dimensional realities of the production via marketing, promotions, and business management.

\section{Navigating transnational Latin music and entertainment}

Of particular importance, is the status of the Latin Music and Entertainment Industry in terms of the market share viable for AfroCuban artists interested in headlining projects in "traditional" and/or non-traditional tropical music and dance. Spanish language music has various forums for showcasing talent in ways that cross broadcast networks, are mainstream, cross cultural, and transnational. To initiate this discussion I employ current images from the 2002 Billboard Latin Music Awards and Conference: Los Premios, the 2002 ALMA (soul) awards, and the recently instituted Latin Grammy Awards (specifically looking at the 2002 awards show). I also include critical scenes from five films: "Buena Vista Social Club," 
"Dance With Me," "The Arturo Sandoval Story," "Piñero,", and "Before Night Falls."

We will then begin to make direct correlations to live shows and televised representations, through a brief discussion of performances by Los Fakires and Ricky Martin, respectively. Compounded, these examples facilitate further exploration of the paradox that shapes the conceptual architecture of Cubanidad. Given the census predictions, and so-called Latin Explosion in music and film, these issues are timely and critical to discussions on black (-)Latino identity.

This explosion has been marked by the late nineties, given the popularity in the world music genre, the Buena Vista Social Club, and the pandemonium surrounding pop star Ricky Martin. With the Buena Vista Social Club's rise to fame, accredited to North American producer, Ry Cooder and Ricky Martin's “groundbreaking” performance at the 1999 Grammy Awards show, artists who, for all other purposes, were considered veterans of the music business were "discovered" by white-Anglo America. This discovery led to a further obsession with things Latin and the subsequent popularity of other previously established artists such as salsero Marc Anthony (New York/Puerto Rico), pop singers Shakira (Columbia) and Enrique Iglesias (Spain).

The more formally structured, commercial Latin Music Industry is in decline. Identifying the cyclical nature of the music industry requires specific points of inquiry as mapped out by Gabe Baptiste, Director of Television, Latin America for Zeal Television USA. According to Baptiste, there is a somewhat infallible pattern to identify the "why" of successful music which is very much involved in considerations of what is popular given the

6 Although this film tells the story of Puerto Rican persona, Miguel Piñero, relevant images in the film help to re-link this study to larger questions of Latinidad. The subsequent discussion of Ricky Martin's performance serves a similar purpose. 
historical/socioeconomic climate. The science of reading and tracking charts, record sales, and venue attendance demystify the highs and lows of the cyclical entity that is the music industry. It is should also be noted that the industry, although a megastructure, is simply one factor in a larger project of cultural production, creation, and consumption. An example of this is evident in the ongoing debates over downloading music, cd burning and resale, and live music that happens in/on/of open public spaces (i.e. streets and parks).

Aspects of the Latin Music Industry (LMI) in the formal sense can be viewed from the major labels and the annual events that celebrate annual accomplishments. In its fourth year, the CBS broadcast Latin Grammy Awards Show marks a new direction in prime time television programming, and the ways in which major players have been pressured to yield to new population and popularity demands.

On Sept. 18, 2002 in Los Angeles, the Latin Recording Academy celebrated the creative spirit, incredible diversity and artistic achievement of Latin music with the third Annual Latin GRAMMY Awards. The first prime-time, primarily Spanish- and Portuguese-language telecast on American TV, the Latin GRAMMY Awards are arguably the most highprofile celebration of Latin culture ever on the domestic airwaves.

(Grammy.com)

As engaged through awards shows such as the Latin Grammy Awards, the ALMA awards, and Los Premios - the Billboard Latin Music Awards, the mainstreamed image, is located in a structure of the interdependent artist, audience, and business. Created and then sold to commercial networks, productions such as the Latin Grammy Awards profit through selective distribution. This results in the images of and within the show being subject to investing networks and sponsors.

The ALMA awards, assessed by name, suggest the theme and thus content of the show, celebrates the soul or essence of Latino identity. This semantic assertion sets the 
premise for the show and renders suspect the predominately white/light skin of presenters, performers, and awardees. Productions such as ALMA reflect only a small sector of the commercial industry and as a result, non-Latin audiences (many of whom are introduced to Latin culture through entertainment) are served a relatively homogenous entity that is "Latin Soul." Likewise, this mytho-reductionist pattern maintains stereotypes of homogeneity and enhances the scarce and mediated inclusion of Afro-Latin identity.

The new generation of Latino artists (based in the United States) reflects a U.S. Latin(o) and Anglo industry that develops artists with crossover appeal. The parameters of this appeal are seemingly demarcated by a polarizing either/or pop and authentic genre identification. This process, as described by Ruth Glasser's study of Puerto Rican musicians from 1917-1940, has not changed much over time. "Once Puerto Ricans stepped into New York recording studios...they were not absorbed into a faceless North American mainstream... [producers/managers/executives] tried to package and sell 'authenticity' while crossing their artists over to as many different audiences as possible" (198-99). Current trends do not promise a space for those who are "too black" or "too authentically African" because of their perceived lack of crossover appeal. What is reaching large masses of people are representations, which restrict AfroCuban and black/non-white Latino/Hispanic identities to "traditional" or "nostalgic" illustrations of movement and sound.

In her discussion of the artistic path of drummer/artisan, Felipe García Villamil, María Teresa Vélez speaks to the opportunities within the music industry that are afforded "folk" musicians such as Villamil. Being that his work is primarily rooted in AfroCuban religious traditions, focusing on batá drumming, he is challenged with specific ideas about how his music is/can be marketed to global audiences. Primarily, this is defined through the 
"world music" genre which tends to superficially associate traditions that have very little in common.

...with the growing popularity of what has been labeled by record companies as 'world music,'... a group of venues (e.g., the World Music Institute) has emerged to present and support the music of immigrant musicians...Musicians or folk artists like Felipe are 'selected' by these institutions according to their own criteria of a authenticity and their political or cultural agendas. Once selected, the artists tradition is reframed according to presentational modes, standards, and aesthetics that have been shaped by the ideology and interests of the presenting institution. (115-6)

Thus, the agency and creative flexibility of the artist is compromised and co-opted and/or reconfigured to the limitations of the mainstream. It seems then, if the artist does not have aesthetic/sound crossover appeal, which provide the most lucrative opportunities for exposure and success, the secondary models remain. Of these models, perhaps one of the most fervent for authenticity is within Hispanic-oriented media. Practices of the mainstream are undoubtedly supported and maintained by misrepresentations of black/Afro-Latinos by other Latinos. The essay, "Hispanic-Oriented Media," identifies Hispanic media as being generated by:

Hispanics from various countries...A significant portion of those [Hispanic Media institutions have been owned, in whole or in part, by non-Latino individuals or corporations, however. But no matter who owned these institutions their employment practices and their content tended to be more favorable to Latinos than other media have been. Whether the Hispanicoriented media are print or broadcast, they continue to present the life and times of Latinos in the United States more thoroughly, appropriately, and positively. (Vélez et al. 225)

This assertion, although perhaps true for white/light Latinos, requires serious considerations of the ways in which blackness and black cultural agents are represented in the content of

7 A collaborative work by Federico Subervi-Vélez with Charles Ramírez Berg, Patricia Constanktakis-Valdés, Chon Noriega, Diana I. Ríos, and Kenton T. Wilkinson 
Hispanic-oriented media projects. How thorough is the representation of Latinos if it "neglect[s] or make fun of the darkest ones..."(Osborne 2000)? In addition, Afro-Latinos, as we will see in chapter three, are rarely employed by said industries as executives. Therefore, welcome contributions are limited to artistic talent and deny positions of power in the business of intellectual-creative production. If black Cubans are marginalized in the business of production, who is left to tell Cuba's stories and whose story is told? How are memoryshadows being employed and distributed, and by whom?

\section{The Image in Film: Memory-Shadows and Mass Representations}

Studies in textual analysis, through cinema and theories of production/reception, lend well to our overarching discussion of the challenges that black Cuban artists face, both as actors within these films, and as performance artists who deal with the perceptions of executives and audiences who inform/are informed by said representations. The incorporation of this form of analysis draws from theories that support a historical and contextual interpretation of film and the incredible influential exchange between film and the social dynamics in/around cinema. ${ }^{8}$

There are virtually no feature films widely distributed in the mainstream U.S. film market (Hispanic-oriented media or otherwise) that depict the complexities of AfroCuban

An important consideration for this discussion, is the Metzian distinction between film and cinema as articulated by Robert Stam:

For Mertz, the cinema is the cinematic institution taken in its broadest sense as a multidimensional socio-cultural fact which includes pre-filmic events (the economic infrastructure, the studio system, technology), post-filmic events (distribution, exhibition, and the social or political impact of film), and a-filmic events (the décor of the theater, the social ritual of movie going). 'Film,' meanwhile, refers to a localizable discourse, a text... (Stam, Film Theory, 110) 
identities. Most story lines and documentaries that more accurately cinematize AfroCuban experiences are created within Independent Film Networks and may be shown at film festivals, colleges, and universities. There are several filmmakers who provide alternative and/or resisting perspectives (Gloria Rolando - Havana, Rigoberto Lopez - Havana, Antonio Romero - Havana), however, they do not reach the masses who have been exposed to films such as: "Before Night Falls," "For Love or Country," "Dance With Me," or "Buena Vista Social Club."

The images in the films discussed here reflect, in many ways, the incomplete or predominately white/light Cuban aesthetic that dominates mass media, mainstream representations of Cubans specifically and Latinos in general. This aesthetic includes, affirms, and may even embrace the contributions of black peoples and African traditions to the mainstream culture of a specific country or region. At the same time, it connotes certain types of blackness (white/light complexion, the "dancing negrita") as appropriate to representations of Cubanidad and Latinidad.

This pattern, which is exemplified in the scenes to follow, illustrate a function of Bakhtinian chronotope, "which mediates between two orders of experience and discourse, the historical and the artistic, providing fictional environments where historically specific constellations of power are [here, directly or indirectly] made visible" (Stam, New Vocabularies, 217). Expanding this concept, said chronotopes as employed, participate in the maintenance and (re)construction of tropes that deny, romanticize, essentialize, and mystify Afro-Latino identities.

The absence of certain images or narrative discourse (Stam, New Vocabularies, 84) has just as much meaning as the presence. The use of black bodies in the background of 
specific scenes and the black body sharing or even being the focus of the scene, amplifies their meaning for the film and the world that the film is attempting to re-create. The meanings for blackness as prescribed by the films mentioned, are the black or mulata as a hypersexual being and the black or mulatta/o in a constant-natural static state of dance and song. They posit black identity and voices as authentic-folkloric, pre-modern, inferior, and Other. Thus, they may be incorporated (for the sake of nostalgia) but not for generic representation.

Released in 2000, "Before Night Falls" featured actor Javier Bardem as the Cuban poet Reinaldo Arenas. Directed by Julian Schnabel, the film is based on Arenas's memoir. The script focuses specifically on the literary achievements and life experiences of Arenas from childhood to death. Paramount, are the opening scenes when the audience is first introduced to "Cuba" and the ways in which a generation of Cuban youth (Arenas's white male contemporaries) made sense of sexuality. By chronology and emphasis, it is implied that Arenas's eventual "deviant" homosexual behavior is determined by specific adolescent experiences. In the film as in the text, a young Arenas:

...danced with Lolín, a young mulatto girl with powerful thighs. In the end, encouraged by some friends, Carlos among them, 1 went to the house across the street to fuck Lolín. We did it by the light of a kerosene lamp, and I remembered my mother in the country. I was nervous and could not get an erection, but Lolín was so adept that she finally got me aroused. Or rather, was it my thinking of Carlos's face while he waited for me outside? In any case, it was the first time I ejaculated inside a woman. (Arenas 36)

Within the context of the novel and the film Lolin is depicted as a seductive mulata, who is perverse and corrupt. The film reproduced the scene, using a light-skin, black female actress who appears to be in her early twenties. Arenas is portrayed as a twelve or thirteen year old boy. Considerably older than Arenas, Lolin, by her seduction of a child, is made 
perverse. Ironically, it is her body and the culture she represents, that is penetrated and essentialized. The memory-shadow takes form and the tragic mulata is revived.

Lolín represents a stage in the maturation of the young white/light skin male. We are reminded of Fanon's discussion of the positioning of the Other. This is one of the few scenes that figures AfroCubans (the other also includes sexual activity) into the film. This is suggestive of the existing segregation (of Cuba-then and Cuba-imagined) and the deliberate positioning of identities. This movement from written text to visual text carries with it questions that should be brought back to the written text and the readers/viewers of both mediums. Why is it that we are hearing the story of Arenas and not Lolín? Whose lives/stories are film-worthy? Whose stories are we interested in hearing and why? And in the absence of Lolín's story, she is marked by the shadow of her historical (Cecilia Valdés) counterparts.

"Dance with Me" featuring Chayanne (Puerto Rican singer) and Vanessa Williams (African-American singer) is a formulaic, storybook-romance type film that engages the difficulties of single-motherhood, interracial dating, migration, belonging, and culture. Directed by Randa Haines; the film was released in 1998. Chayanne plays a Cuban $\operatorname{man}^{9}$ who travels to Texas to find his white-Anglo father; Vanessa is a stubborn, somewhat jaded, instructor and competitive (ballroom) Latin dancer. The two meet and ultimately fall in love.

The apparent assumption in mainstream media that someone who identifies as Puerto Rican can have "generic" appeal and pass as Cuban raises another critical question about representation: Who is employed/authorized to represent whom? Historically, people of color have been subject to mis-representation by white Anglo actors. Although not detailed in this work, it is an important note traditions such as blackface and a history of white-Anglo (several of Italian descent) actors presented as white/light skin Latinos. In regard to Latino representation, parallels can be drawn to the use of white/light Latinos as representative of generic Latinidad, homogenizing distinct ethnic and geographic identities. 
The relevant part of this story, however, occurs, at the start of the film, where we meet Chayanne at home in Santiago de Cuba.

Within the duration of a few minutes, the audience is exposed to his history, his people, and his culture. These are the foregrounding images that construct his reality and that are meant to be used as a resource or a set of codes as we travel (emotionally and physically) with the character. Particularly, during his farewell party we are presented with images of black Cubans, dancing, laughing, drinking, playing drums and guitars, and creating a festive scene. They are out-of-focus, in-focus - auxiliary characters who locate his cultural background in a context that is playful and musical.

The opening scene of the film depicts a black, light-skin Cuban woman with a young girl. We hear the woman call the child's name to wake her from dreaming. Outside of this moment, the black body/voice is silenced until we reach the United States (Vanessa Williams). Dancing and dreaming - these are the preoccupations of the black body and even persists in interesting ways through Williams's character who is scripted as somewhat of a lost soul. Although to dance and dream are not innately negative practices, the repetition and fixedness of black to dance, black to dream, and black to entertain, are highly problematic. "For Love or Country: The Arturo Sandoval Story," also released in 2000, is based on the migration story of the renowned Cuban trumpeter Arturo Sandoval (Andy Garcia). Focusing on challenges seeking asylum in the United States, the audience travels with Sandoval through his experiences in Cuba and migration to Miami. Although most of the film is set in Cuba and the musical influences of Sandoval are rooted in AfroCuban tradition and African-American musical forms, there are few scenes that bring AfroCubans into focus. One such scene concentrates on the interaction between Dizzy Gillespie (Charles S. Dutton), 
Sandoval, Gillespie's video camera, and a group of AfroCuban dancers and singers. The importance of this scene is multiple to this project as the primary dancer is Neri Torres. Torres, who is featured in chapter three, as an artist, has had to negotiate the image she was contracted to portray and the reality of her experiences as an artist.

Here, Torres and other AfroCuban actors are displayed (in the context of the film) as a spectacle, a stop on the tour of Cuba given to Gillespie by Sandoval. In this scene, they are out-of-focus, in-focus, dancing, laughing, drinking, playing drums and guitars, and creating a festive scene. They are no longer extras, or scattered conservatively throughout the background. Yet, as is common practice in the mainstream, black Cubans have been scripted as gatekeepers to the pleasures of life, spiritual cleansing, and sexual liberation. Based on these images, "having" blackness is seemingly having access to these pleasures and spiritual experiences that then service the needs and desires of the white Cuban or Latino in question. What is missing from this story is the legacy of AfroCuban musicians who mentored Sandoval from his childhood.

Sandoval, himself, acknowledges the many black Cuban artists who directly and indirectly have shaped his music and creative projects. As the anecdote goes, there is a photograph of a young Sandoval hanging in the offices of Turi Music, his management company. The photograph depicts Sandoval standing in the midst of a group of adult-male, AfroCuban musicians - he is the only white Cuban present, and an adolescent, at that. This photograph metaphors the creative sensibilities of Sandoval's work in the famous band Irakere and his current group. There is a direct relationship to a tradition of AfroCuban sound and the innovations in Latin jazz that Sandoval continues to create (Sandoval). Although even the most thorough film can not represent the totality of life experiences, the influence of 
AfroCuban traditions and music are central to Sandoval's work. Nevertheless, this aspect is absent, as is the importance of Afro(-)Cuban musicians.

"Buena Vista Social Club," the film, focuses almost entirely on AfroCubans who are the primary subjects of this documentary. The cd and film project, since release, have been the subject of ongoing inquiry. In many ways, the project represents a mytho-reductionist representation of contemporary Cuban music, AfroCuban identities, and the ways in which Cuban society incorporates its history and subsequently its older country persons. Specifically through the film and the reputation of the now infamous, Ry Cooder, this project has been accredited by some as a "discovery" of the lost treasures of Cuba's prerevolutionary culture. This assumes that without Cooder's intervention and Wim Wenders cinematic contributions, this history would remain lost, under appreciated, and marginal.

The reality, however, is that Cooder's overt exoticism and the resulting myths that have infused this phenomenon, created a narrative that minimalizes the complexity of the origins of the project and the lived experiences of the artists that participated in its production. "Cooder's own descriptions of his attraction to working with musicians in the AfroCuban son tradition position Cooder as a foreign explorer in opposition to an 'unspoiled' indigenous Other" (Hernández, The Buena Vista Social Club, 63). The truncated narrative has also resulted in the erasure of Juan de Marco González. González, as Hernández clarifies, was the actual mastermind behind the project which, as told in the narrative, was originally supposed to be collaboration between Cuban and African musicians. González was the link between Cooder and local Cuban artists when the African musicians could not participate and the project had to be reorganized (Hernández, The Buena Vista Social Club, 62). 
Advancing our discussion of performance artists to film, literature, and transnational cultural exchange, the Buena Vista Social Club project marks the iconic nature of cultural productivity and the social/industry climate for the making and reception of things AfroCuban. BVSC is indeed a film about tradition, nostalgia, music, and even includes stories of the lives of the musicians. However, what this film means for representations of blackness and the body of memory-shadows previously discussed is hauntingly familiar. The image of the black body, dancing, singing, and laughing is revived in the documentary.

Repeatedly, black identities/voices are used as a backdrop or a soundtrack for the scene in question or the project at hand. None of these images exists in a vacuum and they all feed into memory-shadows that outline the parameters for representations of blackness in Cuba-telling, mainstream films. The attempt to locate blackness in specific, fixed contexts (i.e. Valdés, Afro-Cubanismo) has survived the journey through the modern and postmodern, across time and space. Ultimately, these images deny the realities of life in the experience, both on and off the island. From the depths of this racialized memory, contemporary revolutionary Cuban society emerges, still drawing from a rich culture palette and struggling with issues of race, cultural production, and national identity. Again, the major point in this discussion is not whether or not these images/themes are included, but rather when and how blackness and the black/non-white body enter. Similarly, in music as in film, the issue of complex representation presents important contributions to the study.

\section{Deconstructing Cubanidad through hip-hop: Figuring the 'new school' in a transnational context}

Here, through examples from the now institutionalized project of hip-hop culture and rap music in Cuba, we will look at certain dynamics of cultural production that inform the 
larger Latin Music and Entertainment Industry in important political and creative projects of transnational exchange. Not only is hip-hop realigning the often-disassociated artistic relationship between what may be called "authentic" black music and so-called Latin music, but also the genre reflects the new school of information that influences many artists who are recent migrants from the island.

According to anthropologist Marc Perry, each year the National Cuban Hip-Hop Festival attracts a fluctuating three thousand attendees, ninety percent of whom are black or brown-skin youth. Identified as a space for, of, and by "gente de color" the festival has drawn international talent such as Black Star (US), Dead Prez (US), Common (US), Square One (Germany), and El Palo Malo (Spain). Held in the large amphitheater of the Alamar neighborhood, the festivals have been coordinated through the organizational efforts of Grupo Uno, Rodolfo Rensoli, Ariel Fernández a.k.a. the Minister of hip-hop, Pablo Herrera, the Hermanos Saiz Association, ${ }^{10}$ and periodically Black August, a project of the Malcolm X Grassroots Movement. The festival also includes more intimate concerts and colloquiums that engage discussion around issues of identity and tradition as they pertain to hip-hop culture.

Occupying varied social spaces, rap music happens in venues such as, Café Cantante, Mi Habana, and Casa de la Cultura traditionally known for live salsa and recorded disco music. Currently, rap is making its way into prestigious venues such as Teatro Nacional, which has been reserved for "classical" (ballet, traditional folkloric) forms of performance. With the increased support from the state, there has been an opening of once exclusively 
"classical" spaces to rap music, thereby re-inventing modes of interaction, access, and exchange within the everyday experiences of the Cuban population (Perry).

The lyrical/thematic scope of the music is varied. It includes, for example, the Lucumí and Santeria influenced content of Orishas. By name and music, they use their craft to honor and acknowledge deities of African based religions, such as Changó and Eleguá. Social commentary is also prominent. Concepto Cuba's song Afuera Acechan Los Demonios (Demons Lurk Outside), includes the lyrics "In my solitude, there is safety, and a way to pass the day...Let them think me crazy. Evil is all around me" (Ramirez). In an interview with journalist Marc Ramirez, the group explained that the lyrics reflect a threat to the community caused by the ills of society (i.e. racism and individualism), which act against the revolutionary project.

The popular group Obsesión espouses a message that addresses important Cuban leaders such as Guevara and Banderas. It speaks of nationalism, black pride and misrepresentation:

I'm black. My intention is not to be a pretty black girl on posters, and if you see me that way I know it's 'cause there still those who want to be the boss, to see me working without rest in the sugar mills, l've suffered this, l've seen this, as Christ also saw it, that's why with one slash of my machete 1 open a path among so many clever poets. In my case I fight because I exist and to find a way to say this.

(Mambí-Rap)

Negating the stereotypes of black/AfroCuban female identity and body image, the lyrics locate a legacy of oppression and marginalization in the historiography of a labor driven color hierarchy. They seem to invoke Changó and possibly Eleguá who are characterized by the machete and the open/cleared path, respectively. Perhaps the depth and breadth of the rhythmic and lyrical talent of Cuban raperos realize a much more intellectually savvy reality than awarded by the protest-syndrome perspective that has dominated the foreign, 
specifically Miami-based, U.S. press? Likewise, the work of such artists suggests a very different image than that presented in the aforementioned U.S. based film, television, and music representations.

As the hip-hop movement gained momentum during the late-nineties, the Black August Project helped shape the way off-island actors influenced the festival. With the contributions of Nehanda Abiodun and other like minded revolutionaries, the involvement of Black August has added yet another geopolitical and transnational dimension. Using youth culture, hip-hop, and activism, the Black August project (based in New York City) works to address social justice issues. With interest in Cuba as a geopolitical symbol of resistance and in support of political prisoners, the Malcolm X Grassroots Movement has collaborated on many occasions with Cuban artists and producers who organize the annual festival (Perry).

Nehanda and others exiled for their anti-hegemony, anti-capitalist, so-called "radical" stance have and continue to be at the forefront of critical theory and activism in spite of the denouncement of a larger geopolitical world order that favors capitalism and globalization. Thus, the involvement of such activists fall in line with a framework that understands the necessary "rules of engagement" for supporting revolutionary thought and action. Recognizing the individual, cultural, and institutional normalization of racism, which manifest through issues of housing, employment, exclusion (via dollarization and tourism) and what may be identified as police harassment, the principles of the revolution allow for self-critique:

I am not claiming that our country is a perfect model of equality and justice. We believed at the beginning that when we established the fullest equality before the law and complete intolerance for any demonstration of sexual discrimination in the case of women, or racial discrimination in the case of ethnic minorities, these phenomena would vanish from our society. It was sometime before we discovered that 
marginality and racial discrimination with it are not something that one gets rid of with a law or even with ten laws, and we have not managed to eliminate them completely in forty years... (Castro)

Cuban raperos express the lived realities of these phenomena through the music and it is within the context of the revolution that many seek to create change. Providing an onthe-ground perspective, Perry undisputedly locates the festival and the music within the structure of the revolution as an "organic" agent working towards a stronger society. Beyond the political slant that has overwhelmed U.S. media (i.e. CNN, the Miami Herald) the music grew from and continues to be a source of entertainment. With the introduction of the festivals, the hip-hop movement has allowed for exchanges with international artists, encouraged tourism, tourist dollars, and served as a social space for artistic expression.

The foreign press has taken this information and mainstreamed a generalized sentiment of denunciation that inadequately reflects the realities of the movement and the annual festival. Sparked by the "controversial" performance of Papa Humbertico in August of 2002 , U.S. based media sources have oversimplified the complex sociopolitical realities and language dynamics of participating artists. As described in a Miami Herald article, "Voicing the frustrations of Cuba's urban youth, musicians followed the lead of American rap pioneers as they opened a festival slamming the police with an irreverence rarely expressed in Cuba publicly" (Sequera 2002). This "slamming" undoubtedly refers to the performance of Humbertico who critiqued several social situations, while performing in front of a banner that read "social denunciation." Fueling several right-wing journalists, the festival has been interpreted as "part of Fidel Castro's campaign to co-opt AfroCuban culture - Santería is another example - into his autocracy" (Kantor 2002). 
Motives for the government's initial support and now virtual management of rap music and the national festival should raise a series of questions, co-optation being one, but also the dynamics of tourism, dollarization, youth outreach, empowerment, and nationalism through media are important considerations. Damian J. Fernández in his article, "Democracy and Human Rights: The Case of Cuba" provides further support for questioning the true agency artists and organizers have over the festival. Comparable to other aspects of civil society, "The state's security apparatus has infiltrated the movement [human rights] in an attempt to dismantle it...the regime is attempting to disarm the internal and external opposition by co-opting parts of its lexicon" (I09-10).

Are rap artists building a counterrevolutionary movement and thus susceptible to infiltration? According to Perry and other present sources, artists are extremely concerned that their critique is being misrepresented as protest. Many artists claim strong sentiments of national identity through the language of the revolution and are disappointed with the post August 2002 press with headlines such as: "The Rap Revolución in Cuba," "Rapping Cuba: A different kind of dissident," and "Cuban hip-hop: The rebellion within the revolution."

It is clear that certain issues are urgent, such as housing, racism, and the marginalization of AfroCubans as employment is redefined by dollarization and increased tourism. However, is it not a disservice to the potential of the artist's work when it is being placed at the center of the (seemingly) eternal debate between the Cuban-American, antiCastro community and those of pro-revolutionary thought... or is this simply part and parcel of the creative process?

This question may lead us to a larger context for thinking about creative processes as/in a socioeconomic political project that moves through levels of (self) identification, 
community, nation, region, and global engagement. Beyond the clear contributions of the arts to the social/leisure structure of a community, it is possible to factor the value of this investigation through the following observations: 1) Cultural production has informed sensibilities on national identity. Likewise, it continues to maintain an identity and a business structure for Cubans working both on and off the island. 2) The space used and the inclusion of international acts at the hip-hop festival speaks lengths to the role culture plays in global bargaining in a hegemonic global capitalism, which is largely influenced/dominated by the United States and fiercely defended by non-state actors such as the World Bank and the IMF. 3) The extent to which conscious or political messages will continue to transcend festivals, nightclubs, and other venues to engage the state in a reflective and productive process is debatable. What is clear, however, is that hip-hop is reclaiming "traditional" forms of AfroCuban music, including samples of old, such as son music and subverting the image of non/apolitical cultural production through direct social critiques. Perhaps the "old" is not as lost as Cooder and Wender's projects suggest?

Hip-hop is challenging the boundaries of globalization and reorganizing the ways in which black youth culture is understood within and outside of the Cuban context. Still, many artists who are interested in continuing these progressive and innovative ways of thinking/doing music that is rooted/routed in traditional forms, find themselves isolated when trying to break into local-Miami and global-Latin Music (mainstream) Industry circuits. To me, it seems to spiral back to questions of authenticity in music and "how and when" black artists and AfroCuban cultural production, here hip-hop, is figured into the schema of staged Cubanidad/Latinidad. Again we are presented with the paradox of Cubanidad and in many ways Latinidad: the problem of authenticity. 


\section{The Paradox of Authenticity: Denying/Reclaiming Routes through Blackness}

Black bodies and at times black voices are used to symbolize authenticity in specific contexts (Gilroy 1993; Moore 1997; Sarduy and Stubbs 2000). There is a color hierarchy that is pivotal to the workings of race and ethnicity in the United States. Often this concept of a color caste stratification is reserved for racialized systems in Latin America and the Caribbean. However, light/dark continuums form rudimentary influences on/in the lived experiences of peoples who are interpellated as black in the United States. Light(er) complexions are usually associated with beauty, "good" hair texture, and other physical attributes that are specifically European. Dark(er) complexions are usually associated with undesired attributes, such as "bad" hair, laziness, and lack of sophistication. Yet, there remains a positive correlation between darker complexions and access to tradition. This continuum measures physical and cultural value from the most desired/desirable to those who are considered less normal, mainstream, and modern. Fundamentally, it measures authenticity. In the process of "reclaiming roots," there is a preferential space allocated to cultures and people who can be identified as pre-modern, exotic, and/or Other. This harks back to the process of reconciling African culture and peoples in the trope of Cubanidad and operates in similar ways for other subsidiaries of Latinidad.

These images have significance for various types of film, performance, and visual art that present aspects of Latino identity. I was struck by the similarities after attending a screening of "Piñero," a film about the Nuyorican poet, activist, intellectual, and actor Miguel Piñero (Benjamin Bratt). Although specific to Puerto Rican identity, the way blackness is used in the film may suggest, that as derivations, Cubanidad and Puerto Ricanness. are functions of Latinidad as an overarching ideology. Similar to "Dance with 
Me" the film opens with an image of an Afro-Puerto Rican woman. We only see her from the shoulders up and her vibrant smile sings drumbeats that score her image.

She is the sexual and the spiritual and means both home and sensuality for the protagonist. Later in the film, this unnamed woman returns with musicians and singers during a party scene. The festivity celebrates the height of Piñero's career. She appears for a third time when Piñero is on his deathbed. She (and the other musicians who are black Latinos) are seemingly the soul and rhythm of this Nuyorican's identity. Soaked in eroticism and exoticism the black-Latina/mulata is a symbol of escapism and the mother/lover of a culture that sees her as both indigenous and foreign to things "Latino." The paradox returns.

Within the arts, certain types of music and dance, typically popular music such as hip-hop, blues, calypso or son music have, historically, been authenticated by black voices and bodies. Many cultural or traditional events rely on the black body and voice to enhance the experience or to evoke nostalgia as in the case of Buena Vista Social Club. Again, Dávila's intervention on generic-appeal is confirmed. "When more recognizably 'ethnic' types are shown, they tend to be presented as signifiers of cultural authenticity, never of beauty of generic appeal" (Dávila 112).

Ricky Martin, who has become a generic symbol of Latinidad, vividly presented this in his performance at the 2000 Miss Universe Pageant held in Puerto Rico. Generally, Martin employs thin, young, male-desiring, female bodies to animate his live performances. This particular performance, however, required a stage full of congas, timbales, light-brownskin male singers, and mostly dark-black-skin female dancers who were costumed in all white. Afro-Latin male percussionists lined the front of the stage with Martin drumming alongside them. Couples of white/light and Afro-Puerto Rican dancers moved about the stage 
space. The featured dancer was a dark-skin, Afro-Puerto Rican woman who danced closely with Martin.

Although it is somewhat rare, for Martin's performances, to see (at the forefront) black/Afro-Latino male musicians in juxtaposed modern and traditional contexts, black/Afro-Latina bodies are highly mediated by the appeal of their complexion, perceived physical beauty, and ability to move their bodies in very specific ways that emulate authentic rhythms. The contrast between the dancers in Martin's usual performances and the black, dark-skin body of the more traditional plena and bomba speak to what is perceived as authentic. It is in these moments that the black body is reconsidered and the terms of engagement are defined.

"It should have been outdoors... Yeah with a breeze and a more inviting space..."

"This is the real, authentic stuff..."

"It should have been more intimate with the band on the same level as the audience... They sound just like Buena Vista Social Club!"

(Comments from white Cuban and other audience members after seeing a performance of Los Fakires)

Los Fakires, an AfroCuban band from Cuba, performed at the Lincoln Theatre on Miami Beach during their 2001 U.S. tour. They are an older group from the generation of Buena Vista Social Club, and to the crowd's pleasing, they played primarily son music and some of the "hits" that are now associated with Buena Vista. Sponsored by the Miami Light Project, the group's performance was well attended and surprisingly met with little resistance, as is the usual case with Cuban-based groups/artists who perform in South Florida. The audience was predominately white Anglo and white Cuban; in fact, many of the black audience members were my own friends or associates. 
After the event. I lingered in the lobby to gather audience reactions. It was clear that several spectators were reacting based on mainstream notions of how authentic black music/musicians should look. The comments above reflect expectations that are clearly marked by notions of Cubanidad and ideas about when and how, in this case, a black Cuban band should be presented. Again, influenced by memory-shadows (BVSC), the memory becomes a collective one, even for a non-Cuban public.

The same presenting company (Miami Light Project) in collaboration with The Rhythm Foundation has brought other performers of a similar period to the Miami area. One such group is Los Muñequitos de Matanzas. A promotional flyer for the performance advertises the group in the following way:

Formed in 1952, Cuba's esteemed 17-piece rumba group began in Matanzas, when a group of young rumberos in a bar started following the rhythms of a song using dishes and bottles. They are now part of the living Legend of Afro-Cuban music, with members spanning three generations, Celebrating their $50^{\text {th }}$ season together.

Although these two groups have been supported by Miami's artistic community, it is interesting to note, that to date, few if any AfroCuban, Cuba-based, hip-hop groups have played in the area. Perhaps raperos and other new school artists do not fit the fixed/static image of the AfroCuban performer as understood in Miamian constructions of Cubanidad in the arts? It is clear that the period of pre-revolutionary cultural production is privileged for visiting artists and as we will see, translates to the opportunities for local artists. 
In CoCo Fusco's English is Broken Here, we are presented with how artist agency can be incorporated into ethnographic work that engages the content and context of their careers. The method of writing about/to/on artists in her text guides the ways in which this project aspires to incorporate cultural agents. Fusco's approach embodies what is often occluded: the resisting subject, who negates, affirms, rejects, and embraces the image. This becomes paramount when discussing the lived experiences of artists. The migration stories of many black Cubans are often overlooked, erased, or denied in accounts of Cuban migration and Cuban American experiences. Similarly, AfroCubans are often underrepresented in the migration stories of other Afro-Caribbean migration accounts as they are realized through resettlement in the United States.

When referencing contemporary Cuban migration stories, certain persisting images are those of the heroic, child/martyr savior (Elian), the criminalized black/gay Other (Mariel), and the brave, political powerhouses of the white/light exile communities. Stories of black Cuban migrants or exiles are often subject to the amnesia of a non-black reality in Cuba save a pantheon of musical genius or the criminalized Other of the Mariel boatlift story. As documented by Portes and Stepick, many white/light Cuban migrants (exiles) feared the threat of the Other (read black, mulatto, gay) Cuban who would indefinitely dismantle the political, economic, and social status achieved by white/light Cubans during 
the first wave of migration. The words of one Cuban-American official reflect the sentiment of many:

Mariel destroyed the image of Cubans in the United States... The marielitos are mostly Black and mulattoes of a color that I never saw or believed existed in Cuba. They don't have social networks; they roam the streets desperate to return to Cuba. (21)

What has been most intriguing in the course of this work is the ability to talk about the image and cultural agents, devoid of the experiences and realities of the performer. Given an overview of certain memory-shadows, we are reminded of Said's argument surrounding the importance of text as images in ideology and the development of self and Other identities. "It seems a common human failing to prefer the schematic authority of a text to the disorientations of direct encounters with the human" (Said 93).

In this chapter I apply the context to the artists who manage this imagined representation of their experiences as cultural agents. This is the departure point for material that details primary research with performance artists ${ }^{11}$ who negotiate the image, its connotations, history, consequences, and presence. Linking sponsorship, creative possibilities, media, and representation to the opportunities made available to Afro-Latin artists, the available roles for black-Latin artists/actors are few and far between. We begin with the experiences and creative projects of Neri Torres. We will then continue learning about the climate for cultural production from other AfroCuban performance artists and industry representatives. Informed by the socioeconomic context of Miami and Cuba (real and imagined) this chapter will reinforce the previous discussion of nostalgia as industry,

$11 \quad$ For varying political and professional reasons certain aspects of migration and industry affiliations have been deliberately avoided. The stories to follow in no way reflect a complete context, but offer important information for advancing theory and participates in the ongoing process of documenting the lived experiences of African diaspora peoples. 
using specific examples of venue spaces. Artist interventions will also speak to authenticity as it is used and contested by/through the cultural agent. Through interviews and participant observation this chapter will address the reciprocal impact of local performance on the global.

They play for Changó...first the batá were played inside the house allowing the drummers to speak with Chango and then they moved to the backyard for the rest of us to dance...the lead prayer singer poured an oil-based liquid on the floor and one by one each person dipped their fingers in it and made a symbolic mark on their forehead and neck... spraying ${ }^{12}$ the drummers and singers... the practitioners continued to dance... They play for Eleguá... she moves about the floor -- searching ---her eyes wide as she stumbles pointedly about the small crowd, she cowers and lets out sharp tones...

she is being mounted by Changó---another woman's body begins to jolt, she is about to catch the spirit and backs away from the drummers...in avoidance?--- They play for Yemayá. She is now Changó, a santera adorns her body with red and black cloth (the colors of Changó)... her body is made holy...moving in and out of the house Changó ate, laughed, and consulted with his children... and most impressively Changó danced... Changó danced.

\section{Neri Torres and Ife-Ile, Inc.}

The ritual, the movement, and the transition from sacred to secular drive the work of many artists who identify with aspects of AfroCuban religious culture. Through drum, dance, lyric, and/or theme, many performance artists invoke ancestors and express religious traditions in their work. The preservation of the innovative and lasting meaning of these cultures is the driving force behind Ife-lle, Inc. The transnational linkages between dance, music, and sacred/secular performance provide critical resources for the dialogue amongst 
artists, creyentes, ${ }^{13}$ and scholars who seek to route the movement of the Orishas and their children. Subsequently, many artists (in Cuba and abroad) who perform both the folkloric and sacred, also participate in more commercial, secular genres.

Torres's expanding company is one of the two major AfroCuban dance and performance troupes (the other being Iroko) in the South Florida area. Founded by artistic director, Neri Torres, the group has been in existence since May of 1996 . They provide weekly dance and drumming classes, master classes, showcases, and major events such as an annual dance and music festival. I first met Neri during Ife-lle's 2001 AfroCuban festival. The event included a theatrical performance, films, dance and drumming workshops, poetry, and a closing night party at the upscale Cuban restaurant Café Nostalgia. It was here that I was struck by Neri's vibrant, assertive, and inviting personality.

Creative energies aligned, 1 knew immediately that her vision for education, art, and cultural preservation were similar to my artistic and academic projects. After a few brief exchanges, I expressed interest in working with the company and we agreed to meet at her studio in Little Havana. The space itself consists of a padded dance floor, a wall of mirrors, hanging speakers, stereos, various drum sets and maracas adorning the corners and walls. The walls also frame several plaques commemorating achievement and mayoral recognitions of the talented ensemble. Although small, Torres manages to conduct several weekly classes with approximately five to fifteen students, regular company rehearsals, and business meetings.

13 "believer; religious adherent or practitioner of Santería or another Afro-Cuban religious tradition" (Hagedorn 245). 
At the back of the studio is a cramped office space, the administrative nucleus of the nonprofit organization. It is here that Neri negotiates contracts, writes scripts and treatments, registers new students, and reviews the scores for upcoming performances. About the office are stacks of compact discs that reflect her influences from rap to rhythm and blues, Latin jazz, to guaguancó, son to salsa, and more. Personal photographs sit on a short video shelf that includes several tapes of Conjunto Folklórico, and other Orisha/AfroCuban religiousoriented performance artists. Atop a four-draw file cabinet there are books on Santería, arts education, and dance technique. There are posters from performances at various venues across the country and stacks of books on local and international grants.

Like most artists I would meet, Torres, a free agent, performs several tasks including artistic direction, talent recruiting, promotions, marketing, and public relations. Clearly the organization or company faces different obstacles than the solo artist, however, the politics of performance are often quite similar. Although Torres has a long-standing career as one of Gloria Estefan's choreographers and dancers, she continues to struggle to make a name for herself. Work with Estefan has included some of the traditions that her company is most recognized for. "Cuban dance troupe Ife-Ile performed a joyous rendition of classic AfroCuban folkloric dance complete with percussionists playing guaguancó on boxes, and (Gloria) Estefan screened a 'home slide show' featuring pictures of her parents in Cuba, her own childhood and her two children" (Shore C6). However romanticized the account or the performance, Torres has found ways to negotiate traditional and commercial settings, while maintaining the premise of her work and cultural heritage.

Rarely commenting on her work with the Estefans, Neri prefers to concentrate on her career and her company as independent projects. The concept for Ife-lle came from 
Neri's artistic insight and innovation, based on observations of current trends in the music scene. According to Torres, the early nineties marked an important period in the "underground" to commercial exposure of hip-hop music, multiculturalism in the mainstream, and another chapter in mainstream U.S. interest in Latin music. She also noted the way hip-hop dance was theoretically and literally bringing dance back to the earth. Brilliantly, she linked the tradition of many African and AfroCuban dances that concentrate on the body's relationship to the ground/earth as a source of life and balance, to hip-hop dance. She makes these associations through the similar use, for example, of flat foots, stomping, bended backs, and downward shoulder movements. Such movement is visible in the many techniques and combinations of break dancing. Artistically, she made critical connections and envisioned a company that could link communities, cultures, and also preserve the spirit of her heritage.

Her vision, however, did not correspond with the trends in casting and hiring at the commercial level. There was and perhaps still is an unhealthy, disjointed, severed relationship between many African-American music and dance forms and the legacy and wealth of tradition in Cuban culture. She identifies this period as a (trans-temporal) "crisis in creation." Torres was frustrated with the lack of opportunities for black women in the arts. After going on several auditions and wondering if the rejection had to do with her hair, her body type, her dress, or her skills as a dancer, she came to realization that it was the intersection of her identities as a black woman and hiring practices that implied that "black was not in." She was faced with the questions: When and how is black in? What are the terms of engagement for the black image and the black artist? 
As a result of these experiences, Neri felt creatively, spiritually, and professionally that she needed to "create opportunity" by become a managing player in the larger arts/entertainment industries. Beginning with five dancers, she is now in the company of a fluctuating group of approximately fifteen dancers and five to seven musicians. In a short time, Torres has developed an organization that works on various commercial and traditional levels. Their repertoire includes a rich mixture of traditional and contemporary Afro(-)Cuban/Latin dance and music. This field includes ritual dances of the Orishas, conga, chancleta, son, salsa, and mambo.

A family oriented project, the company includes her brother, Ezequiel Torres, an acclaimed drummer. Ezequiel, an artist in his own right, has made contributions through drumming and the crafting of batá drums, to the livelihood of AfroCuban religious culture in Miami (Cantor). A sister, Natividad, is an accomplished poet, activist, teacher, and spiritual leader. She often reads poetry and gives academic/activist lectures at annual festivals and related events. In addition, Aruan and Arulan Torres (sons of Ezequiel) function as the primary drummers and raperos for the group.

Arriving to Miami just over three years ago, they were very much influenced by the hip-hop culture of the island. Building from their work in Cuba, Aruan and Arulan have contributed greatly to Neri's vision to reunite the sound and movement of AfroCuban traditions and hip-hop. This has fueled ideas for a possible album and new integrations of the story-telling feature of Ife-Ile's theatrical productions with hip-hop as new oral tradition. Challenging notions of Cubanidad and AfroCuban performance, Torres is unpacking the myth and educating Latin and Anglo audiences, alike. Informed by folkloric, religious-based 
performance troupes in Cuba and trained by the National Ballet Company, Torres has carved out an ethnoreligious commercial space in the white/light Cuban aesthetic culture of Miami.

When asked how her work fits into the schema of Miami given larger questions of the "Latin Explosion" and Afro-Cuban artists as imagined/imaged in the mainstream, she gives a laugh and says pessimistically, "There is no Latin boom, or invasion as it is sometimes called, because this music has always been there." Perhaps the "invasion," which is used to characterize recent Latin artists in mainstream U.S. media, is a perverse distortion of the true invasion: the peaking and waning curiosity and resulting devaluation of a culture, based on the desires/fantasies of dominant cultures. Revisiting the Buena Vista Social Club project, we might configure Cooder's "discovery" as another example of white Anglo curiosity, exotification, and capitalism at work. There are many groups and individual artists, such as those in BVSC in both Cuba and the United States. Torres suggest that the same project "...could have happened right here in Hialeah."

The allure of authenticity, however, will always locate the Other in a theoretical and geographic space that seems most real, genuine -- hence the age, style, and location of the group and the resulting popularity. Torres, although appreciative of the music that was shared with the world, is also wary of identifying this project as representative of the current direction of Cuban music. She instead wants to draw attention to the linkages between contemporary forms of music in the U.S. and Cuba. As expressed by many artists I spoke with, the past is revered as something consistent in present and future. There is an almost counter-linear approach to artistic creation that makes the "past" integral to this method of cultural production. 
"Authenticity" myths are being negotiated and resisted, by artists, on a daily basis. As such, one of the most interesting times to see the creative-intellectual depth of Neri's company is during the annual festivals. Previously called the "Afro-Cuban Festival," the program as of this year has been renamed, "BailaUSA." This change allowed for a more diverse representation of Afro-Latin culture and was a strategic move to attract a broader audience. During the 2002 festival entitled BailaUSA: Beats of Africa in Latin America the group provided programming with a creative, historic, contemporary, and critical purpose. The street festival included local and international bands that played everything from classic rhythm and blues, to reggae, to salsa. Classes included the drumming workshop, From Orishas to Timba, which demonstrated how sacred instruments and rhythms have been incorporated into secular music. Also offered were films such as, "Nosotros la música," by Rogelio Paris and "Más voltaje, más volumen. El rap en Cuba," by Wen Trup. Torres organized lectures on the aesthetics of Yoruba Lucumi traditions and a panel, on which I sat, entitled: "The Current State of the Black Image in Film and Television in Latin America and the Caribbean."

Attendance at lfe-lle's festival, however, speaks to the lack of interest and support by the white Cuban community. As observed by Nadine Fernández in her occasional paper, "Miami Cubans in Black and White: Racial Myths and Denials," there are thousands of Cubans (most of whom are white) who attend the annual Calle Ocho festival, which is a celebration of Latin-Cuban-Latino culture. Similar festivals, organized by white Cuban artists and businesses have a large following and confirm that there is an interest in cultural events. The question is, whose culture is of interest? Although on the surface it appears that of all aspects of inclusion, the arts is the most open, black Cuban artists continue face 
obstacles around the establishment of lucrative and recognized spaces of/for cultural production.

Some of these obstacles arise in the organization of major performances that require intense amounts of energy and creativity, for as Torres explains, "coming from a certain tradition of theatrical production, we are used to large shows that use live music, have several scenes, set changes, and detailed lighting." The resources, however, are not there and so when preparing for a large show she often supervises (if not executes) choreography, set design, costumes, budget, booking logistics, tickets, promotions, interviews, program development, typing, mailings, songwriting, and the list goes on. Although highly skilled, Torres is extremely overworked and hopes for the day when she can do more delegation and be able to focus on her primary talent and passion, dance and choreography.

This, however, requires a stable staff which requires a larger budget. Currently funded by a host of small grants, she is able to take care of rent and expenses for dancers and musicians. As a non-profit, she has received grants to do master classes, workshops, performances, and demonstrations at universities, with children/youth groups, at facilities for those who are differently-abled, health clinics, and community festivals. The next step is looking for a larger grant from institutions such as the Ford Foundation, that would allow her to implement plans for a spacious facility, capable of functioning as a site for teaching, production, performance, and community building.

Aware of the many challenges faced in the United States as a black woman and in Miami as a black Cuban woman, Torres perseveres. In honesty, she does have aspirations of moving to New York City, aware of the different sociocultural climate. Based on the experiences of other artists and the expressed interest of audiences, she is assured that her 
projects would be well received. Yet, she stays in Miami because, "I am stubborn. I want to see this happen and it needs to happen. Cubans are a diverse people and the loss of AfroCuban traditions and styles to the [new transnational identity in the U.S.] culture is very sad..." Even if the next few years finds Torres in New York, she will continue to work in Miami. There is a commitment to making sure that AfroCubans are not shadowed by the myth of a white/light Cuban sociocultural reality.

\section{-Additional Perspectives from Artists and Industry Representatives}

\section{Luis Bofill, Vocalist}

A modest stage supports the weight of six musicians including an assortment of percussion instruments, timbales, congas, a guitar, keyboard, and an unforgettable voice. Luis Bofill's melody falls on the discernable instruments that begin the classic bolero "Preciosa," as interpreted by Marc Anthony. The song is dedicated to the few Puerto Rican patrons in a crowd. There is a familiar relationship between the band and crowd signifying that many are regulars or friends of the artists. Full of energy, Bofill welcomed me to the venue Havana Dreams Café, one of many nostalgia-themed venues that cater a multigenerational audience of mostly white/light Cubans. Although primarily a restaurant, the space is transformed into a comedy/dance/music space on Friday and Saturday evenings. After a brief introduction to the owner, with whom Bofill has worked for several years, we proceed to the business office to conduct the interview.

Born and raised in Cuba, Bofill arrived in the States in 1996 as an aspiring artist. He and a friend, who played the guitar, would perform at baby showers, weddings, and other 
festive events. After a few years and exhausting self-promotion, Bofill established a solid reputation, and landed a job singing at the highly acclaimed Café Nostalgia at the Forge. This experience resulted in the album "Café Nostalgia Live," a mix of classic and contemporary Latin music. Soon to follow were the solo albums: "Te Di La Vida Entera," "El Son de Juan" (BMG), and "Do Re Mi." Influenced by Benny Moré, Robert Tofas, Al Jareu, and Bobby McFerrin, his solo work reflects a fascination with vocal experimentation and innovative projects that stylistically/thematically represent past, present, and future.

When asked about the current state of cultural production, Bofill speaks of a new movement -- a new generation of musicians who are young and vibrant. "They are dedicated to the past, yet eagerly moving into new ways of making and performing music." On the subject of Buena Vista Social Club's popularity and the affect on AfroCuban musicians, Bofill replies, "Yes, Buena Vista and other similar artists are important, but there is so much more...we are so much more!"

South Beach, Miami -- Telemundo and Univision news crews hover around the crowd approaching the check-in table at Billboardlive. The club sits at the end of the infamous Ocean Drive and towers over storied shops and restaurants. By invitation only, attendees ascend the stairs to the club entrance. They are here to join in the celebration of Arturo Sandoval's many achievements and signing with Emilio Estefan's label, Crescent Moon. 
When I entered the venue, I was visibly the "darkest" person there and navigated the exclusive process of entering and exiting the levels of the club (VIP, reserved company sections) The black body -- particularly my black female body is absolutely and fundamentally foreign and given the unwavering stares, perhaps suspect in this space. On the main stage, Emilio Estefan and other executives applaud Sandoval and proclaim, "This is a big day for Latin music and for Jazz!" Estefan continues to list Sandoval's accomplishments as he approaches the stage to join the family. All the while, my eyes are fixed on Ernesto Simpson, Sandoval's percussionist. Later in the evening, with the help of a friend, I manage to introduce myself to Simpson and tell him about my work. We exchange information and he agrees to meet with me later in the week.

\section{Ernesto Simpson, Percussionist}

A self-agent, Ernesto Simpson plays private parties, weddings, and international shows with the Arturo Sandoval band. From a cameo appearance in "For Love or Country: The Arturo Sandoval Story" to his work on the score of films and television productions, he has developed a unique portfolio. He incorporates AfroCuban music theories into American jazz, works with swing, salsa, timbales, conga, and batá drums. In 1970, Ernesto began his career studying "classical" music and found it impossible to abandon AfroCuban religiousbased sound. Determined to be an artist of culture and innovation, he learned several musical styles. An avid student of the conga and batá drums, he continues to translate these highly complex techniques to other types of drum instrument and style. Also part of this exchange 
are a distinguished group of drummers, whom he admires. These musicians include, Vinnie Colaiuta, Jeff Watts, Jack de Johnette, Elvin Jones, and Peter Erskine.

As an emerging artist in Cuba, his "big break" was with Sandoval's band. After leaving Cuba, Ernesto started teaching in Bogotá, Colombia and then moved to Miami where he hopes to teach again. In the meantime, he conducts master classes and showcases for the University of Miami (UM) and Florida International University (FIU). During our initial conversations in 2001, Simpson expressed his adoration for Miami. "It is like Cuba in many ways, but different in other very important, political and social ways. There is more freedom to create..."

When asked about challenges he has faced working in Miami as a black Cuban artist, he states that he has not encountered much discrimination. When people "stare" at him, he says, "perhaps they think I am exotic, or just a good drummer...or pretty." He has never viewed this as negative, but ponders the possibility and asks me if $I$ have ever encountered racism. When I tell him yes, he pauses and shakes his head in disbelief. Or sympathy? He is silent and then responds, "Hmm...maybe it is there and I chose not to see it. I was very fortunate to reunite with Arturo in Miami. Playing with his [U.S.-based] band has made things easier than if I was working on my own," This affiliation and subsequent endorsement helped reestablish Simpson as a reputable musician in a transnational context. On several occasions, Sandoval has called Simpson his "favorite drummer" and did not think twice about reuniting with him in the States (Sandoval). Members of Sandoval's production staff call him the "joker" of the group. In settings, (absent of Sandoval) Simpson adopts a leadership role amongst the musicians with whom he works. 
One evening, we met in the charming and intimate upper room of the Van Dyke Café. Located on Lincoln road in Miami beach, the venue serves as a bar/restaurant/jazz club. Every other Thursday, for several months, the venue would host a night entitled "Caribbean Jazz." The band consisted of music professors from FIU and UM, a local steel pan player, and Simpson on drums. Commonly, the crowd is mostly white, Anglo, and few in numbers. With sunglasses and a flashing earring in the left ear, Simpson sips on a Red Stripe and surveys the space. The band is taking a second break for the evening.

Usually, they will play three sets with two breaks from nine in the evening to one in the morning. Much like this evening, Ernesto will perform with different bands in a host of local venues. He sometimes receives perquisites such as complimentary drinks, preferred parking, or free admission for guests, depending on the venue. The pay varies, but is often minimal given his talent, draw of local music students, and affiliation with Sandoval. Competing with the sound system, I explain my project in further detail. His eyes light up and he offers to share information about his experiences and craft. As the evening progressed, he would point out things I should observe and frequently asked "What have you observed tonight?" After this warm reception I attended "Thursday night at Van Dyke" several times over three months and brought various friends and colleagues to support the artists.

Simpson and I eventually developed a wonderful friendship and he would invite me to closed rehearsal sessions with Sandoval's band, social events with friends and fellow musicians in the local jazz scene, and backstage after major shows at FIU and the Calle Ocho festival. After attending six or so sessions with Arturo's band, I became familiar with the members. Many, like Simpson, were Cuban and had recently arrived in Miami. Although 
limited, exposure to their work, as solo artists and with other bands, revealed a stark contrast to Ernesto. Most were white Cubans and although they worked the local scene, they were not as vigilant as Simpson. Maintaining a modest standard of living, the other artists seemed much more comfortable living and working in Miami than Simpson. There are several variables that contribute to comfort levels, nevertheless this is an important distinction.

Approximately a year after our first meeting, Simpson was struggling to maintain regular performances at venues in South Beach, Coral Gables, and North Miami. Several owners stopped supporting the work due to "a [local] lack of interest" in Afro-Latin jazz. Just two years later, Simpson decided to move with his family to New York. "There is no work here," he confesses. Although still under contract with Sandoval, Simpson needed more opportunities for practice, passion, and most importantly, economic stability. His current schedule confirmed his expectations. He now plays several sets a week and has been able to return to Afro(-)Cuban percussion through events such as a Cuban film and music festival. Simpson has also developed reputable relationships with important establishments such as the Blue Note Café.

Lázaro, Producer

"Because you're black you have to 'rub' hands with the white boys to succeed," Lázaro says beginning our phone interview. We had met a few weeks before at a informational session for people of color interested in arts management. A self-identified black Cuban man, Lázaro began his music and entertainment career as a trumpet player, joining the Marine Corps. Band as a teenager. Within a few months of playing with the band, he discovered that he was also quite good at marketing and promotions. This career was cut short, and as a young man, he left Cuba and traveled to the United States in search of better 
opportunities. Lázaro arrived in Atlanta and attempted to reestablish himself as a trumpeter. When he found little or no market for "an AfroCuban identified trumpet player," he focused on artist management and promotions.

Now, relatively successful in this work, he manages performance artists in Atlanta and South Florida. Identifiably, he is one of the few black Cubans working in the management aspect of Miami's entertainment industry. He considers himself "lucky" to be in this position because, "We (black people) need to elevate ourselves...nobody will give it to you, you have got to see what they (white people) have and how they got it. Then you take that information and share it with other black people." He recognizes the challenges that many artists of color face and humbly attributes much of his success to the opportunities afforded by African-Americans who "took a chance on him." It is in this way, through other (non-performance) sectors of the industry, that Lázaro has been able to re-enter the Latin music scene as a key player.

After working in Miami for several years, Lázaro has observed that it takes a "house name," generally a white Cuban (in Miami) to validate the talent of black Cuban artists. "A 'white-boy' house name can bring in anyone (artists and audiences) and they will be cool...but on your own, especially for blacks, it becomes very difficult." According to Lázaro, some of the challenges for local musicians are exposure, stability, and appropriate compensation. "Black Cuban artists might play for two-hundred dollars a night when the market allows for much more lucrative and stable contracts. Sometimes four piece bands will walk away dividing no more than three hundred dollars."

Although stability may seem a questionable variable for a discussion of the arts, the nature of Miami as a tourist city and the importance of music and dance spaces afford several 
opportunities for artists. One of the major problems, however, is what and how AfroCuban artists are expected to perform. If they fall outside of the "image," work becomes harder to find. Similarly, with few AfroCubans in venue or artist management positions or as headliners, the options for exposure, dynamic artistic projects, and subsequent economic success are limited. After just a few interviews and several attempts, I was unable to contact Lázaro or the production company for which he worked.

\section{$\sim$ The Venues of Nostalgia}

I walked inside the small, crowded club and made my way across the room to an open space. The dance floor was full of couples dancing to salsa from Eddie Palmieri to La India. A friend, who was aware of my research interests, recommended that I visit the popular club and restaurant. After ordering a mojito (a specialty), I leaned against the bar and surveyed the crowd. Although dark, I could make out several photographs and paintings that hung on the wall above the bar. The walls were adorned with pictures of mostly musicians and dancers, most of whom were black and "mulatto/a." Then a screen lit up behind the stage and a montage of black and white vignettes played silently. There were images of the dark-skin black man dancing, the mulata dancing, Benny Moré, Celia Cruz, a group of black children smiling -- the camera pans up and they are standing beneath a statue of Jose Martí.

I wondered if my discomfort was visible. Perhaps I would not have felt so uncomfortable if the crowd was more diverse. From the corner of my eye, I could see people 
watching me, watching these images. I looked around and again sensed wonderment as to how or why I was in this space. I was the only black person there....more so the only nonwhite-skin person in the room? Wait, I see someone. I smile and wave. It is Tommy, a percussionist I had met through Ernesto. He waves back and signals that he is going to talk to someone. He walks up to another black man... he is in the band as well. I continue to watch the crowd and make an effort to take notes on a square paper napkin.

\section{〜Feeling/Doing Cubanidad: Hoy Como Ayer}

Hoy Como Ayer is a small neighborhood space gone underground with an eclectic mix of live son, DJ funk, silent black and white vignettes of pre-revolutionary Cuba, and a multigenerational, predominately white, Cuban audience. Catering to those "in search of the past," the club is a mainstay in the neighborhood. Located in the heart of Little Havana on Calle Ocho, the most popular night, to date, draws a few hundred patrons each week for Fuácata! Thursdays. The featured band is DJ Le Spam and the Spam All-Stars, a group comprised of AfroCuban, white North American, and black Anglo members. They mix prerevolutionary Cuban music, disco salsa, funk, and jungle beats, and attract a twentysomething crowd. The night takes a new spin on the "traditional" or old school Cuban sounds that are invoked by the very name of the club. Advertisements for the night read:

For those who are feeling...more Cuban-American...the nights at Hoy Como Ayer, are a must, especially Thursdays. This is the night, Dedicated...to the Cubans that grew [up] in Miami. Hoy Como Ayer, [will] allow you to enjoy your Latin roots and feel free like the wind. Named Fuácata!, this night... [stars]...DJ Le Spam... with a live group. On the background some images of the island are displayed.... ${ }^{14}$ 
In addition to offering this night geared towards a younger generation of CubanAmerican's, Hoy Como Ayer also hosts musical comedies, a jazz evening, Jazz ta' Bueno, on Wednesdays, and a general salsa, rumba, and bolero night on Saturdays. And every so often, there will be a special event, featuring groups such as Ife-Ile, or celebrating holidays and historic moments. It was on one of these nights that I witnessed many of the dialectical elements of cultural production, Cubanidad, AfroCuban performance, and socioreligious identity, coexist in a particular space. The celebration of patron saint, La Caridad del Cobre and/or/as Ochún/La Virgin attracts the crowd this evening. She, in her light-skin representation, stands, glorified, and surrounded by various offerings, and hundreds of white candles. Juxtaposed to this altar, which sits against the wall, there is dancing, drinking, smoking, and flirtation.

On this particular Saturday evening, the venue is both sacred and profane (Eliade) drawing from atmosphere, staged performances, and audience engagement. It is a meeting of the Cuban nightclub, AfroCuban dance and commercial batá drumming, nostalgic imagery, Catholicism (invoking generic Cubanidad), and Orisha (implied through Ife-Ile) worship. This space cues further investigation into the participation of a commercial traditional dance and music ensemble in the business of cultural preservation through the arts and the significance of Santería in the re-creation of critical socio-spiritual experiences.

The possibilities for Cubanidad are challenged, as Ife-Ile performs traditional and contemporary song and dance. They present tradition and remove "folklore" from its novel, limiting, and sensationalistic context. 
"Where did you learn how to dance? Most gringos don't know how to dance unless they take lessons." A white Cuban woman questioned as I walked off the dance floor. Until that moment I had felt comfortable there as an observer - and as a dancer. The obvious class difference, between myself and some of the other guests did not bother me as much as I anticipated. Several people commented (with surprise) on my ability to dance bachata, salsa, and merengue. Once I established "belonging," through dance, stares were diverted and men and women found a way to communicate with me. In fact, some patrons asked if I was from Cuba. Having been asked this question before, it became clear that individual choices are made, at particular moments, to read black, dark-skin as Cuban or as AfricanAmerican/Other. How and when these choices happen are still to be explored.

\section{$\sim$ Positioning the Other at Home: Café Nostalgia at The Forge}

The front of the sister club to Hoy Como Ayer, opens into a reception area that is full of advertisements, paraphernalia, and celebrity photographs. A young woman sits behind a display case/desk reviewing paperwork. Ife-Ile's singers take the stage and begin singing a series of Yoruba chants. I approach the young woman and inquire about the club. "The idea is to create a place where Cubans can feel at home and experience a classy atmosphere. You see all those pictures, they are people who remind many Cubans of the way things were. The club also connects younger Cuban-Americans to the history." This "connection" to home and "history" is largely represented by AfroCuban images, in still-motion-live form. From photographs, to vignettes (as with Hoy Como Ayer), and life size cardboard cut outs, black Cubans dominate the aesthetic edge of the restaurant. 
I then moved the conversation to this particular evening, where past and present, image and subject, were playing off each other. The traditional, sacred, secular, and commercial performance of the ensemble stood in immediate resistance to the still, static imagination of Cubanidad manifest in ambiance. When I asked the woman whether or not she liked Ife-Ile, she said in a slightly lowered voice, "It can be a bit frightening, but this is a mild form...My mom was into this, but I was always a little scared, but this is ok...It is your culture you know..." This nondescript "it" I imagine to be AfroCuban religious culture and traditions. Fear, avoidance, and assumptions of belonging are part of her understanding. She has positioned the subject, here myself, and the Other, here AfroCuban culture.

Glimpsing into the stream of play on cultural identity and the actual work and lived experiences of artists, these vignettes intend to open a space for a directed look at the processes of and for production. They also give breathing room for making sense of the proposed theoretical interventions. At the present moment, new directions in local endeavors are subject to the politics of financially capable artists who are able to execute their solo/group projects. More often than not, however, the direction of fully financed projects, broad in market share and content, rely on established parties in dominant Anglo and white Cuban communities who are interested in collaborating with or investing in Afro-Latino artists and projects. Based upon interviews and current industry trends one of the major areas of development to be explored is the live music arena. This has always been a critical space for any artists because of the potential to "break," nurture, or stifle new artists. Thus the importance of venues that support AfroCuban artists, as they are, rather than as they are imagined or expected to be. 
Miami is becoming/has become a scene that thrives off of DJ-world beat fusion and dance music. Within this context "traditional" or folkloric entertainment must be able to do a variety of things in different settings. This shift can be an opportunity for artists such as Torres to actually bring her visions to the forefront. For more "conventional" theatre and dance projects, local interest seems to be waning, as is the most recent Anglo affair with things "Latino." In the midst of this, however, there are exciting things happening within spaces such as Hoy Como Ayer, with DJ Le Spam and the Spam All-Stars. 
Conclusion: Contextualizing the Journey - Linking Labor, Ideology, and Culture

Playing Miami: AfroCuban Performance Artists Negotiating Cubanidad asserts blackness as a source for authentic Cubanidad articulated by the Industry of Nostalgia and related arts and entertainment projects in Miami. Likewise, the formal and informal systems of the Latin Music and Entertainment Industries participate in the maintenance of a white/light Latino aesthetic. This aesthetic is visible in both Anglo and Hispanic-oriented television and film programming. Successful and emergent artists from the "Latin Explosion" illustrate the highly mediated inclusion of blackness in the factoring of crossover appeal and as an extension, generic Latinidad. Similarly, the climate for AfroCuban cultural production in Miami is congested with the influence of a white Cuban cultural aesthetic. Through fusion-oriented projects, however, the artistic scene is undergoing a generational shift towards a reclamation of African roots.

The staged performance is the journey and carries shadowing memories in its temporal and geographic travel. The process of redefining the self as an artist in time (authenticity-modernity), region (Cuba-Miami), and trade (performing arts) is located in a context that contributes to larger issues of subaltern cultural production, Diaspora art, and cultural preservation in a transnational context. The politics of labor, identity, and culture, here addressed through AfroCuban artists, can offer insight into an overarching discussion of African diaspora cultural production. 
To conclude our discussion, we will venture to a discourse that propels the presented research into the overarching matrix of transnationalism, Afro-Caribbean migration, and the dialectical relationship between the imagined black body, modernity versus authenticity, ownership, and perhaps the most pervasive memory-shadow: the neo-colonial project that sustains ideologies of the Other and the fixed/static image of AfroCuban artists. Through the interdependent factors of labor, ideology, and culture, I release this study to the chronologically concentric interactions of said factors for further studies in transnationalism, cultural production, and cultural preservation.

Media and media production continue to be central to understanding social dynamics. The masses, civil society or "the people" both constitute and generate the future of global and domestic social spaces. It is from the experiences of the masses, often derived from the arts, that we are given information about historical moments and contemporary struggles. In his work, Main Currents in Caribbean Thought Gordon Lewis presents several concepts that demarcate the parameters of interdependent factors that construct a working prospectus for the Caribbean. Through descriptive, comparative and contextual study, he employs the support of several theories and development models to identify the sociohistorical context for contemporary movement of the region and its Diaspora.

Labor, ideology, and culture are not only critical to the way the Caribbean has developed, but also to the way it is envisioned and thus acted upon or approached by global politics, mainstream media culture, intellectual institutions, and economic development endeavors. In fact, the underlying theme of this work, although specific to AfroCuban artists, is relevant to post-colonialism or neo-colonialism as revealed in questions of the authentic versus the modern. The difference is in the details and the way these details (at times fact, at 
other times mytho-factual) have been acted upon and realized within specific sociopolitical, economic, and social contexts.

The dialectical relationship that the black body has had to issues of labor and ownership continue to haunt the Western defined "progress" or modernization of the Caribbean. "All of its members [Caribbean region] have been shaped throughout by the same architectonic forces of conquest, colonization, slavery, sugar monoculture, colonialism, and racial and ethnic admixture" (Lewis 3). To say that the desire for, manipulation of, and possibility in labor informed the socioeconomic, political, and cultural development of the Caribbean would be an understatement. Labor in/as service, continues to mark the black subject and shape perceptions of the Other which are rooted hierarchies of color and stratified, complexion continuums from "light" to "dark."

Largely, entertainment and leisure, as previously discussed, have been associated with the black body. As a result. cultural production has been denied the full scope of possibility as theory, therapy, activism, heritage, and work. This association has resulting in the co-optation of culture and the normalization of entertainment as advancement based on the successes of select actors, singers, dancers, and sports figures. In this context, labor and resulting capital carries with it infinite affects on the way cultural production happens within Caribbean countries and their metropoles, such as Miami.

Moving from labor to ideology brings with it the knowledge that power is consistently oscillating between the dominant and the Other. Particularly, Lewis speaks of the ideology of ethnicity and ethnic relations as they tie into leadership, class structure, colorclass hierarchy and myths of inferiority. Said myths sustain the colonized mind and inform structures of governance, interpersonal interactions, and intra/inter-territory operations. The 
ideological authority that shaped the colonial era(s) included a perceived right of conquest, religiously supported systems of inferiority, and perceptions of the Other, and the use/ownership of land -- similar to the manifest destiny of early North American societies. The materialization of ideological thought in wealth and power continue to hold Caribbean and U.S. African diaspora societies in its grip.

Lastly, in the context of popular culture, where its study is disproportionate to its importance, Lewis makes several significant, but at times minimal, attempts to illustrate the role of the arts, religion, and spirituality in the "values, norms and modes of selfconsciousness..." (Lewis 21) National and regional identity (specifically for diasporic communities) relies heavily on the development of these dimensions of society and is part of Caribbean intellectual production and what has been termed Caribbean Thought. It is here that I would depart from the framework that Lewis has put forth and suggest that we involve the arts as integral to the historical and contemporary possibilities for economic development, (inter)national identification and interpellation. We should envision cultural production as terrain for critical theoretical production from within subject communities.

The memory-shadows of distorted representations through whiteness, in the context of the arts and religion/spirituality, have compromised the black body and exaggerated a "natural talent" for professions which, historically, have been classified as "low" art. The paradox is that there has always been, again as expressed by Moore, a desire for popular art. Thus, the task of incorporating "low" culture into "high" culture has depended on the stereotyping of a people, disregard for their contributions in other fields, and the sabotage of their accomplishments in the arts. The negotiation of this history, as exemplified through Torres, Bofill, Simpson, and Lázaro , is embodied in the lived experiences of artists who are 
constantly battling the mainstreamed image and subsequent interpellation by a dominant culture as inescapably and indefinitely "Other."

This Otherness is then co-opted, re-configured, and appropriated by the dominant culture. In order to make sense of this dependency, the mainstream has incorporated certain elements of the marginal and named it folkloric, traditional, or nostalgic. Commenting on this process and its relationship to "Others" within the United States, Jose Flores states that,

Midway through its two-hundred-year life since the late eighteenth century, the idea of popular culture began a gradual shift of focus from this traditional, collective creativity, commonly called 'folklore,' to the domain of the mass media, the 'mass culture' of technical reproduction and industrial commercialization. (Flores 17)

Folklore, tradition and nostalgia are concepts that participate in a larger discourse on modernity (and post-modernity), which is critical to the configuration of blackness and "African" culture in a U.S. mainstream context. Within the United States, then, AfroCubans become an Other within the Other and serve as nostalgia for one system of thought (Cubanidad) and as both invisibly and ominously objectified/exoticized in another (U.S. Latinidad/Hispanidad). Authenticity, which links folklore, tradition, and nostalgia, thus enters as a function of difference semiotics, as discussed in chapter one, manifest in media.

Given our discussion of memory-shadows, it becomes evident that the power of the authentic image and the relational value of that image to the lived experiences of artists onthe-ground, require critical dialogues on how images are generated and normalized by/through the mainstream. It is the position of artists and their experiences that at times affirms, and often dismantles, the myth of a level playing field where musicians and dancers can work without being compromised by the contexts within which they find themselves. The politics of the entertainment industry and the participation of this industry in the 
ideological constructs of Cuban (self-identified exile) politics, the stratified cultural topography of Miami, and the ominous presence of U.S. racism, undoubtedly distort the psuedo-objective nature of cultural production.

Addressing only the surface of many complex contextual issues, this study serves as a starting point for further research in several areas. Viewing the performances of selfidentified and/or socially classified AfroCubans has offered invaluable insight into the workings of Cubanidad. Fortunate to work with supportive participants, the amount of information gathered exceed the immediate scope of this thesis. As a dissertation, this work would investigate patterns of inclusion among artists based on the amount of time they spend living and working in Miami. Most artists expressed a desire to move out of South Florida to places like New York or the Bay Area where they feel they would have more work. Further development would also include extended interview and performance accounts, propelling the study to the next logical stage. Although centered on Miami, much time was necessarily invested in setting the scene or "the climate" in which AfroCuban artists work. Only then, are we able to appreciate the complexity of the experience.

There are also several questions left for the Latin Music Industry. This work is one aspect of a possible larger study of the experiences and absence/presence of black Latino artists in the designated "crossover" pool. As such, this project is critical to both the industry and black/Latino studies. New directions in Latino studies are undertaking questions of black identity and building upon important work on white/light Latino Othering. Collaborative intellectual endeavors could answer important questions around Miami's pervasive segregation, the challenges for the Other when trying to operate as an 
owner/producer, and will add another crucial level of analysis to the critique of the "Latin Explosion" trajectory.

\section{$\sim$ Additional questions for moving beyond the text}

How do we as artists of color re-imagine/manage ourselves in a field that capitalizes on appropriating our work and our identities? How does an artist break through nostalgia and introduce innovative work? And the questions remain: Are we approaching the juncture of the image? Is the image re-articulated? Or perhaps we (specifically in the United States) are stuck in the harness of the embargo, moving across dimensions yet motionless in production and likewise disjointed from the movement within Cuba itself? How are these images/myths changing? Are they changing at all?

We. as a global community, are faced with a multidimensional, historically informed task. More specifically, given current geo-political contexts Caribbean peoples at home and abroad must be agents of change defying geographic boundaries with the same vigor and ingenuity as globalization, mass commodification, and like imperialist projects. By both capital and imagination, we must continue to "move from the margins," investing in creativeintellectual projects that de-mystify contemporary trajectories and reconstruct the path. 


\section{Works Cited}

Alfonso, Harold Dilla. "The Cuban Experiment: Economic Reform, Social Restructuring, and Politics," Latin American Perspectives 27 (2000) : 33-44

Aparicio, Frances R. "Jennifer as Selena: Rethinking Latinidad in Media and Popular Culture," Latino Studies 1.1 (2003) : 90-105.

Arenas, Reinaldo. Before Night Falls. Trans. Dolores M. Koch. New York: Viking Penguin, Penguin Books USA, Inc., 1993.

Bennet, Eric. "Hip-Hop History." Encarta Africana. 12 December 2002. $<$ http://www.africana.com/research/encarta/tt_239.asp $>$.

Boyce Davies, Carole. Black Women Writing and Identity: Migrations of the subject. London: Routledge, 1994.

Cantor, Judy. "The Beat Generator." Miami New Times. 7 August 1997: 13

Census Data 2000. American FactFinder. 6. March 2003. $<$ http://www.factfinder.census.gov/ $>$.

Cornelius, Steven. Rev. of Nationalizing Blackness: Afrocubanismo and Artistic Revolution in Havana, 1920-1940. by Robin D. Moore. Notes Dec. 1998: 400-402

Dávila, Arlene. Latinos, lnc.: The Marketing and Making of a People. Berkeley: University of California Press, 2001.

Davis, Fred. Yearning for Yesterday: A Sociology of Nostalgia. New York:

The Free Press, 1979.

de la Fuente, Alejandro. A Nation for all: Race, Inequality, and Politics in Twentieth Century Cuba. Chapel Hill and London: The University of North Carolina Press, $200 \mathrm{I}$.

do Nascimento, Abdias. "Pan Africanism, Negritude and the African Experience." Conference on Negritude, Ethnicity and Afro Cultures in the Americas. Florida International University, Miami. The Symposium on Pan-Africanism and the African World. Dakar, Senegal. 1987.

Derby, Lauren. Rev. of Nationalizing Blackness: Afrocubanismo and Artistic Revolution in Havana, 1920-1940, by Robin D. Moore. The American Journal of Sociology 913 (1998)

Eliade, Mircea. The Sacred and The Profane: The Nature of Religion. San Diego: Harcourt, lnc., 1987. 
Fanon, Frantz. Black Skin, White Masks. New York: Grove Press, 1967.

FIU/CUBA Poll 2000. Institute for Public Opinion Research. 6. March 2003.

$<$ http://www.fiu.edu/orgs/ipor/cuba2000/>.

Fernández, Damian J. "Democracy and Human Rights: The Case of Cuba."Democracy and Human Rights in the Caribbean. Eds. Ivelaw L. Griffith and Betty Nelly SedocDahlberg. Boulder: Westview Press, 1997.

Fernández, Nadine. "Teaching Cuban Identity in Miami through Dance: White Hispanic vs. AfroLatin." Latin American Studies Association Conference. Adam's Mark Hotel, Dallas, Texas. 29 March 2003.

---. "Miami Cubans in Black and White: Racial Myths and Denials." Pre-LASA Symposium: Race and Anti-Black Racism in Latin America. African New World Studies, Florida International University, Miami. 15 March 2000.

Flores, Juan. From Bomba to Hip-Hop: Puerto Rican Culture and Latino Identity. New York: Columbia University Press, 2000.

Foucault, Michel. Language, Counter-Memory, Practice: Selected Essays and Interviews. Ithaca, N.Y.: Cornell University Press, 1977.

Godfried, Eugène. "Reflections On Race \& The Status Of People Of African Descent In Revolutionary Cuba." November 2000. 16 October 2002.

$<$ http://www.afrocubaweb.com/eugenegodfried/reflectionsonrace.htm>.

Gilroy, Paul. The Black Atlantic: Modernity and Double Consciousness.Cambridge: Harvard University Press, 1993.

Glasser, Ruth. My Music Is My Flag: Puerto Rican Musicians and Their New York Communities 1917-1940. Berkeley: University of California Press, 1995.

Godfried, Eugène. "Reflections On Race \& The Status Of People Of African Descent In Revolutionary Cuba." November 2000. 16 October 2002. $<$ http://www.afrocubaweb.com/eugenegodfried/reflectionsonrace.htm $>$.

Grenier, Guillermo J. and Lisandro Pérez. The Legacy of Exile: Cubans in the United States. Boston: Allyn and Bacon, 2003.

Hall, Stuart. "What is this 'black' in black popular culture?" Stuart Hall: Critical Dialogues in Cultural Studies. Eds. David Morley and Chen Kuan-Hsing. London: Routledge, 1996. 
Hernández, Deborah Pacini and Reebee Garofalo, "Hip-Hop in Havana: Rap, Race, and National Identity in Contemporary Cuba," Journal of Popular Music Studies, $11-12(1999 / 2000): 18-47$

Hernández, Tanya Katerí. “ 'Too Black to be Latino/a:' Blackness and Blacks as Foreigners" Latino Studies 1.1 (2003) : 152-59.

Jordan, June. Technical Difficulties: African-American Notes on the State of the Union. New York : Pantheon Books, 1992.

Kantor, Myles. "Rapping Cuba: A different kind of dissident." National Review Online. 5 September 2002. 16 October $2002<$ http://www.nationalreview.com/comment /comment-kantor090502.asp>.

Lewis, Gordon K. Main Currents in Caribbean Thought. Johns Hopkins, 1983.

Lipsitz, George. Time Passages: Collective Memory and American Popular Culture. Minneapolis: University of Minnesota Press, 1990.

Moore, Robin D. Nationalizing Blackness: Afrocubanismo and Artistic Revolution in Havana, 1920-1940. Pittsburgh: University of Pittsburgh Press, 1997.

Munoz, Lorenza."Young Filmmakers and Musicians Create a New Revolution in Cuba." Los Angeles Times on the Web. 16 December 2000. 19 October 2002. $<$ http://64.21.33.164/CNews/y00/dec00/19e9.htm>.

Ojito, Mirta. "Best Friends, Worlds Apart." The New York Times Online. 5 June 2000. 19 April 2002.<http://www.nytimes.com/learning/general/featured_articles /000606tuesday.html\#>.

Osborne, Wendell A. “An Open Letter to Univision.” 25 June 2000. 19 May 2002 $<$ www.afrocubaweb.com>.

Perez Sarduy and Stubbs, eds. Afro-Cuban Voices. Gainesville, FL: University Press of Florida, 2000.

Portes, Alejandro and Alex Stepick, eds. City on the Edge: The Transformation of Miami. Berkeley: University of California Press, 1993.

Ramirez, Mark. "Young Cubans Turn to Hip Hop." The Washington Times on the Web. 16 February 2002. 16 November $2002<$ http://www.cubanet.org/CNews /y02/feb02/18e6.htm>.

Robinson, Eugene. "The Rap Revolución in Cuba, an Insistent Musical Voice is Pounding Home Its Points and Protests." The Washington Post. 14 April 2002: G01 
Roy, Maya. Cuban Music. Trans. Denise Asfar and Gabriel Asfar. Princeton: Markus Wiener Publishers, 2002

Said, Edward. Orientalism. New York: Vintage Books, October 1979.

Sequera, Vivian. "Cuban rappers show rare outspokenness about the nation." The Miami Herald Online. 18 August 2002. 24 March 2003. <http://www.miami.com/mld/ miamiherald/news/world/americas/3885331.htm>.

Stam, Robert. Film Theory: An Introduction. Malden, Massachusetts: Blackwell Publishers, 2000.

---. New Vocabularies in Film Semiotics. London: Routledge, 1992.

Sutter, Mary. "Madonna's Latin Music Machine." Ocean Drive Magazine Online, December 2000. 1 April 2003. <http://www.oceandrive.com/magazine/dec_2000/madonna/>.

Umlauf, Simon. "Cuban hip-hop: The rebellion within the revolution." $\mathrm{CNN}$ Headline News Online. 25 November 2002. 16 October 2002.<www.cnn.com/2002/showbiz/music/ $11 / 22 / \mathrm{hln} /$ hot/hit.cuban.hip.hop>.

Subervi-Vélez, Federico, Charles Ramírez Berg, Patricia Constanktakis- Valdés, Chon Noriega, Diana I. Ríos, and Kenton T. Wilkinson. "Hispanic Oriented Media." Latin Looks: Images of Latinas and Latinos in the U.S. Media. Ed. Clara E. Rodriguez. Westview Press, 1998. 225-237.

Wynter, Sylvia. "Columbus, the Ocean Blue, and Fables That Stir the Mind: To Reinvent the Study of Letters." The Poetics of the Americas: Race, Founding and Textuality. Eds. Bernard Cowan and Jefferson Humphries. Baton Rouge: Louisiana State University Press, 1997. 141-164.

Vélez, María Teresa. Drumming for the Gods : The Life and Times of Felipe García Villamil,Santero, Palero, and Abakuá. Philadelphia Temple University Press, 2000 


\section{Interviews}

Baptiste, Gabriel. Personal Interview. 3 Dec. 2002.

Bofill, Luis. Personal Interview. 7 Feb. 2003.

Cobo, Leila. Personal Interview. 12 September 2002.

Del Granado, Bruno. Personal Interview. 3 Dec. 2002.

Lázaro. Telephone Interview. 15 Nov. 2001.

Martin, Ricky. "Up Close and Personal with Billboard's Leila Cobo." Interview. Billboard Latin Music Conference. Eden Roc Hotel, Miami. 8 May 2002.

Perry, Marc. Telephone Interview. 3 Dec. 2002.

Sandoval, Arturo. Telephone Interview. 16 Nov. 2001.

Simpson, Ernesto. Personal Interview. 18 Nov. 2002.

Torres, Neri. Personal Interview. 3 March 2003.

\section{Selected Filmography}

Before Night Falls. Dir. Julian Schnabel. Perf. Javier Bardem, Olivier Martinez, Andrea Di Stefano, Johnny Depp, Sean Penn, and Michael Wincott. Fine Line Features, 2000.

Buena Vista Social Club. Dir. Wim Wenders. Artisan Entertainment, 1997.

Dance With Me. Dir. Randa Haines. Perf. Chayanne, Vanessa Williams.

Columbia/Tristar, 1998.

For Love or Country: The Arturo Sandoval Story. Dir. Joseph Sargent. Perf. Andy Garcia, Mia Maestro, Gloria Estefan, David Paymer, and Charles S. Dutton.

HBO Films, 2000.

Piñero. Dir. Leon Ichaso. Per. Benjamin Bratt, Giancarlo Esposito, Rita Moreno, and Mandy Patinkin. Miramax, 2001.

Representation and the Media: Stuart Hall. Northampton, MA: Media Education Foundation, 1997. 
AfroCuban Dance. Neri Torres, Instructor. Dance class. Ife-lle Dance Studio, Miami. 12 April 2003.

Arturo Sandoval and the Latin Connection. Concert. Wertheim Performing Arts Center Florida International University, Miami. 16 Nov. 2002

Bata-Rumba Jam: $3^{\text {rd }}$ Annual Ife-Ile Afro-Cuban Festival After Party. Ife-Ile, Inc. Concert. Café Nostalgia at the Forge, Miami Beach. 5 October 2001.

Jazz ta' Bueno. Carlos Averhoff Quartet feat. Ernesto Simpson. Concert. Hoy Como Ayer, Miami. 17 Oct. 2002.

From Afro-Cuban to Salsa. Neri Torres, Instructor. Dance workshop. Miami Dade Community College, Miami. 4 Oct. 2002.

!Fuácata! Spam Allstars. Concert. Hoy Como Ayer, Miami. 12 Sep. 2002

---. Spam Allstars. Concert. Hoy Como Ayer, Miami. 14 Nov. 2002

---. Spam Allstars. Concert. Hoy Como Ayer, Miami. 16 Jan. 2002

Ife-lle BailaUSA Street Festival. Concert. Miami Dade Community College, Miami.6 Oct. 2002.

La Familia Cepeda in Concert. Ife-Ile, Societe Koukouyu and La Familia Cepeda. Concert. Miami Dade Community College, Miami. 5 Oct. 2002.

Miami Light Project Presents: Los Fakires. Concert. Lincoln Theater, Miami Beach. 16 Nov. 2001

Premios Billboard de la Musica Latina, After Party. Billboardlive, Miami Beach. 9 May 2002.

The Rhythm Foundation and Miami Light Project Present: Los Muñequitos de Matanzas. Concert. Gleason Theater. 9 April 2002.

A Tribute Reception: Arturo Sandoval. Arturo Sandoval and band. Concert. Billboardlive. Miami Beach. 14 Nov. 2001.

\section{Selected Recordings}

Roig, Gonzalo. Cecilia Valdés : Cuban Operetta. Montilla, 1960? 